\title{
5
}

\section{Sport and EU competition law}

In applying EU competition law to sport, the Directorate General for Competition Policy (herein referred to as the Commission) has been caught between three powerful forces. First, the Commission has a constitutional commitment to promote and protect the free market principles on which much of the Treaty of Rome is based. In this capacity it shares a close relationship with the ECJ. The ECJ's rulings in Walrave, Donà and Bosman have played an important role in placing sport on the EU's systemic agenda in a regulatory form. The Commission has a constitutional obligation to follow the ECJ's line of reasoning on sport, given its role in enforcing ECJ rulings. As such, sport has passed on to the EU's institutional agenda through the regulatory venue, the prevailing definition stressing sports commercial significance over and above its social, cultural and educational dimensions.

The second major influence on Commission jurisprudence in the sports sector is administrative. Although primary and secondary legislation has equipped the Commission with the necessary legal powers to execute this commitment, it lacks the necessary administrative means to carry out formal investigations into abuses in all sectors of the economy. In the face of a large and growing caseload, the Commission has had to adopt creative means in order to turn over cases. In particular, the Commission has resorted to the use of informal procedures to settle cases rather than adopting formal decisions. For some time it has been felt by Commission officials that the procedures for applying competition law are in need of reform. It is within this context that in September 2000, the Commission proposed a regulation to devolve its competition powers to national courts and regulatory agencies. ${ }^{1}$ The proposed Regulation seeks to establish a system whereby 'both the prohibition rule set out in Article 81(1) and the exemption rule contained in Article 81(3) can be directly applied by not only the Commission but also national courts and national competition authorities'. ${ }^{2}$ This would in effect end the Commission's monopoly over the application of Article 81(3). Whilst the Commission's proposal acknowledges that the system worked well with six member states, the monopoly has created difficulties for the 
uniform application of competition powers in an enlarged EU. However, the very reason for needing reform may hinder the viability of the Commission's proposal. For national regulatory bodies to play a more active role in applying competition law requires familiarity with existing practice in case law. Due to the resource problem, the Commission has however settled many cases through negotiation rather than formal channels. In areas such as sport, where the use of soft law is most pronounced, case law precedents are thin.

The third pressure is political. Although the Commission has been fairly successful in shielding itself from close member state control, it does not operate in an environment immune from the wider political context. The EU's institutional agenda is very open and affords actors the opportunity to exploit a multiplicity of venues in order to influence policy. As such, once an item reaches the institutional agenda a range of actors can become involved in the policy debate. In the case of sport, not all have accepted the definition of sport adopted by the ECJ and the Commission. The application of EU competition law has evolved in the context of an on-going debate in the EU as to the real nature of sport. Should sport merely be seen as an economic activity or does sport possess social, cultural and educational values worthy of protection from law? The member states have emerged as a powerful advocate of this more broad-based approach to sport. This has involved the construction of the separate territories approach for sport. The Commission is central to the construction of this approach, although, as is discussed below, the proposal to devolve competition powers (particularly the exemption procedure) to national regulatory authorities may pose some difficulties for the construction of the separate territories.

The Commission's constitutional obligation to safeguarding the fundamentals of the Single Market has therefore had to be balanced by administrative and political pragmatism. The Commission has generally adopted a two-fold strategy. On the one hand it has consistently followed the ECJ's line that sport is subject to EU law whenever practiced as an economic activity. This allows the Commission to claim that the fundamentals of the Single Market have not been compromised. On the other hand, the Commission has been willing to recognise sports social, cultural and educational values when considering the applicability of exemptions. In this connection, the Commission has to make a distinction between rules that are of sporting interest only and rules which have commercial implications. As the Commission has acquired more experience in these matters so it has been more active in formulating a competition law separate territories approach. The Commission hopes that this approach will add more legal certainty to what is a relatively new area of Commission activity.

This chapter explores these issues in six sections. The first section reviews EU competition law, concentrating in particular on restrictive practices and abuses of dominant positions in the Single Market. The second section 
examines the generic relationship between sport and competition law. Should sports rules fall within the scope of competition law? Sections three, four and five analyse the specific relationships between sport and competition law. The sports market comprises three markets (Egger and Stix-Hackl 2002: 85-87). The exploitation market, in which clubs and federations exploit secondary features of their performances such as broadcasting rights, exclusive distribution networks for ticket sales and merchandising arrangements, is considered in section three. Section four analyses the contest market where the actual product, the sporting contest, is made. Rules concerning the organisation of sport are addressed in this section. Section five examines the supply market - the market in the buying and selling of players. The final section examines the Commission's general approach to sport by reviewing the sports-related case law within the context of the Commission's paper on the development of a framework for the application of competition law to sport, the first formal exploration of the viability of constructing separate territories of sporting autonomy and competition law.

\section{European Union competition policy}

Article 3 of the EC Treaty states that the activities of the Community should include the establishment of a system ensuring that competition in the Single Market is not distorted. Following the signing of the Treaty of Rome, the precise nature of this system was set out in Articles 85-94 of the Treaty (now 81-89). The two Articles most relevant to the sports sector in Europe are Articles 81 (ex 85), dealing with restrictive practices by undertakings and Article 82 (ex 86), concerning the abuse of a dominant position by an undertaking.

Despite the Treaty base for competition policy being established by the Treaty of Rome, a fully fledged competition policy did not come into operation until the passing of Regulation 17/62 establishing the procedures for applying the competition provisions contained in the Treaty. Although this body of primary and secondary legislation granted the Commission considerable scope for applying competition law, it was not until the 1980s that it began to fully exercise the full potential of their powers. Doern and Wilks identified three reasons accounting for this. First, the EU entered a new phase of development in the 1980s as domestic neo-liberal ideas found expression at the European level through the exercise of tighter rules of competition. Second, the political leadership of Sutherland and Brittan contributed to the visibility and the maturation of the Directorate General for Competition Policy. Third, through this leadership, the Commission sought innovative ways of expanding the scope of European competition policy, the creation of the Merger Regulation being the highlight of this activity (Doern and Wilks 1996: 232). By the 1990s the Commission had established a strong reputation for itself. However, the problem of a lack of resources persists. 
This problem has resulted in a slow turnover of cases and the increased use of administrative procedures rather than formal decisions to decide cases.

Today, competition policy is exercised with both economic and political objectives in mind. In economic terms, the competition provisions are consistent with the free market ethos that underpinned much of the Treaty. Only in selected areas such as agriculture can an overtly protectionist agenda be detected. The belief in the market mechanism was clear, but only by enforcing strict rules of competition can the EU hope to establish many buyers and sellers within the market which would help improve the allocation of resources and in turn benefit consumers. As competition policy has evolved, so these rules have been central to the establishment of a more economically and politically cohesive Single European Market and increasingly a tool for helping European undertakings compete in the global marketplace.

\section{Article 81}

Article 81 comprises three paragraphs:

1 The following shall be prohibited as incompatible with the common market: all agreements between undertakings, decisions by associations of undertakings and concerted practices which may affect trade between member states and which have as their object or effect the prevention, restriction or distortion of competition within the common market, and in particular those which: a directly or indirectly fix purchase or selling prices or any other trading conditions;

b limit or control production, markets, technical development, or investment;

c share markets or sources of supply;

d apply dissimilar conditions to equivalent transactions with other trading parties, thereby placing them at a competitive disadvantage;

e make the conclusion of contracts subject to acceptance by the other parties of supplementary obligations which, by their nature or according to commercial usage, have no connection with the subject of such contracts.

2 Any agreements or decisions prohibited pursuant to this Article shall be automatically void.

3 The provisions of paragraph 1 may, however, be declared inapplicable in the case of:

- any agreement or category of agreements between undertakings;

- any decision or category of decisions by associations of undertakings;

- any concerted practice or category of concerted practices,

which contributes to improving the production or distribution of goods or to promoting technical or economic progress, while allowing consumers a fair share of the resulting benefit, and which does not:

a impose on the undertakings concerned restrictions which are not indispensable to the attainment of these objectives;

$\mathrm{b}$ afford such undertakings the possibility of eliminating competition in respect of a substantial part of the products in question. 
Accordingly, for Article 81 to apply a number of conditions must be met. First, it must be determined by the Commission that an agreement between undertakings, decisions by associations of undertakings and concerted practices has taken place. Although the term agreement is not defined in the Treaty, the Commission has usually adopted a wide interpretation of it. Similarly, the term undertakings is not defined and again the Commission's wide interpretation brings into the definition any entity engaged in economic or commercial activity involving the provision of goods and services. Undertakings whose activity only generates a small profit and even nonprofit undertakings are included in this definition. Should such entities co-ordinate their activities they may be described as associations of undertakings. Anti-competitive effects stemming from decisions by associations of undertakings also fall within the scope of Article 81. Such decisions need not be formally constituted. For example codes of conduct have been regarded as decisions. If undertakings co-ordinate activity between themselves in such a way as to fall short of an agreement, then this behaviour may amount to a concerted practice.

The second condition required for Article 81 to apply concerns the nature of the agreement. Article 81 seeks to prevent agreements which have as their object or effect the prevention, restriction or distortion of competition within the Single Market. Article 81 itself lists some agreements which distort competition. The definition of anti-competitive agreements has widened through the jurisprudence of the Commission and the ECJ. For instance in the Consten case the ECJ extended the scope of Article 81 beyond horizontal agreements (for instance, agreements between undertakings operating at the same level in the system of distribution) to vertical agreements (for instance, agreements at different levels such as between producers and distributors). ${ }^{3}$ Furthermore in Consten, the ECJ argued that if it can be determined that the object of the agreement was the prevention, restriction or distortion of competition, the agreement can be condemned without further market analysis of its impact. Therefore such an analysis is only required in circumstances where the agreement in question has the effect (and not the original intention) of being anti-competitive. Agreements which are of minor significance will not be caught by the provisions of Article 81 and will therefore be subject to the de minimis limitation. In such circumstances and others where the agreement falls outside the scope of Article 81(1), the Commission will issue a negative clearance. Negative clearances constitute a formal decision.

The third condition relates to the requirement that the agreement must affect trade between member states. Agreements which only affect trade within one member state or agreements the impacts of which lie outside the $\mathrm{EU}$ are unlikely to be caught by the scope of Article 81. The ECJ has given guidance concerning the calculation as to whether an agreement affects interstate trade patterns. ${ }^{4}$ 
The Commission can become aware of potential illegalities in a number of ways. First, it can launch its own investigation. The Commission's powers of investigation are considerable and are detailed in Regulation 17/62. These include the power to request information, the ability to scrutinise documentation and ask on the spot questions and the right to enter premises. Second, as the Commission currently has a monopoly over the right to issue exemptions, a self-notification system is in operation for undertakings to inform the Commission of agreements and practices. Finally, individual complainants bring potential abuses to the attention of the Commission.

Having become aware of potential competition violations, the Commission must resolve the case. Again, a number of options are available to it. First, due to the political and administrative pressures the Commission works under, many cases are settled through informal channels. Undertakings seeking a negative clearance or exemption from Article 81 will notify the agreement in question to the Commission. Following the notification, a series of informal consultations between the relevant party and the Commission takes place. Aspects of the agreement which the Commission objects to are removed. The Commission then usually issues a 'comfort letter' informing the party that the agreement does not infringe Article 81(1) or that an exemption is suitable. These letters do not hold the legal force of a Commission decision but are a useful way of communicating the Commission's views. Frequently, the undertakings themselves favour this negotiated settlement. The problem with the informal soft law approach is that the legal environment is not clarified. Firms are not guided by the legal certainty formal decision making creates. Particularly in relation to the regulation of new sectors such as sport, the lack of legal principles often creates confusion (see below). The Commission is aware of this and has introduced a more formal comfort letter which it publishes in the Official Journal. This gives them a more formal appearance and notifies interested third parties of the 'decision'. This allows third parties to submit observations prior to the Commission formally closing the file. In addition, the Commission has relied heavily on other informal tools to communicate their position. These include press releases, notices and annual reviews. As with comfort letters, these tools hold no legal effect. The cumulative impact of them in establishing de facto precedents is however considerable.

The second method of resolving cases involves the Commission taking a formal decision to grant negative clearance. The Commission follows this course of action if it believes that the agreement or practice falls outside the scope of Article 81. The third method involves the Commission finding that an agreement infringes Article 81. In these circumstances it will send a statement of objections to the relevant parties outlining the case against them. Once the parties have responded to the statement of objections a hearing is convened. In effect the Commission acts as prosecutor and judge. A formal decision of a finding of infringement may result from this procedure in which 
case the Commission can declare the agreement void (Article 81(2)). The Commission also has the power to issue interim orders.

The final method involves applying the exemption criteria outlined in Article 81(3). Agreements which contribute to improving the production or distribution of goods or to promoting technical or economic progress, while allowing consumers a fair share of the resulting benefit, may be exempted from the application of Article 81(1). Under the provisions of Regulation $17 / 62$, the Commission has the power to grant individual and block exemptions. An individual exemption can only be granted if the agreement in question has been notified to the Commission. Formal individual exemptions issued by the Commission can only be granted if the four conditions contained in Article 81(3) are applied. Exemptions are published in the Official Journal and are reviewable by the Court of First Instance (CFI) and the ECJ on further appeal. The formal process of issuing individual exemptions is however time consuming. A lack of resources and the requirement to issue speedy decisions has contributed to the wider use of the Commission's informal procedures for communicating their thoughts on a particular agreement. For these reasons, the Commission has also made more use of the block exemption procedure. Block exemptions are more generic in nature and cover particular agreements in a whole sector. In addition to the Commission, the Council has the legal right to issue block exemptions under the authority of Article 87 (State Aid). Examples of block exemptions include Liner shipping agreements and motor vehicle distribution agreements (Goyder 1998: 131). ${ }^{5}$ The Commission's proposal to amend the procedures for applying competition law by replacing the current system of self-notification with a devolved competition regime involving national courts and national regulatory authorities will, if accepted, affect the current system for granting individual exemptions (see above). ${ }^{6}$

\section{Article 82}

The focus of Article 82 concerns:

Any abuse by one or more undertakings of a dominant position within the common market or in a substantial part of it shall be prohibited as incompatible with the common market insofar as it may affect trade between member states. Such abuse may, in particular, consist in:

a directly or indirectly imposing unfair purchase or selling prices or other unfair trading conditions;

b limiting production, markets or technical development to the prejudice of consumers;

c applying dissimilar conditions to equivalent transactions with other trading parties, thereby placing them at a competitive disadvantage;

$\mathrm{d}$ making the conclusion of contracts subject to acceptance by the other parties of supplementary obligations which, by their nature or according to commercial usage, have no connection with the subject of such contracts. 
To establish whether Article 82 applies to any given context, the Commission must identify the existence of two conditions. First, it must establish whether an undertaking has a dominant position. Second, it then has to decide whether it has abused this dominance. It is the abuse of dominance and not the sheer existence of dominance that is illegal. In this connection, the Commission must demonstrate that the abuse has had an appreciable impact on trade between member states. Unlike Article 81, there is no provision for negative clearance or exemptions under Article 82.

A position of dominance is potentially anti-competitive because within the relevant market, an undertaking may have such power that its behaviour has a negative impact on competitors and consumers. In order for the Commission to establish whether an undertaking has a dominant position it must define the 'market'. This involves determining the relevant product market and the geographical market. The definition of the market is important because if effective competition exists within the market, the effect of an anti-competitive agreement would be limited and even self-defeating for the offending undertaking. The product market refers to 'all those products and/or services which are regarded as interchangeable or substitutable by the consumer, by reason of the product's characteristics, their prices and their intended uses'. ${ }^{7}$ The wider the product market is defined the more difficult it is to identify dominance. Substitutability refers to the ability of consumers to obtain similar goods within the relevant market (demand substitutability) and the ability of undertakings to supply similar goods (supply substitutability). The Commission often employs the 'SSNIP' test to determine substitutability (Weatherill 2000: 275). According to this test the Commission must decide whether consumers would switch to other goods in response to an increase in the range of 5-10 per cent in the price of the good in question. Defining the geographical market is important as Article 82 is only breached where dominance occurs within the common market or a substantial part of it. In this instance the wider the market is defined, the easier it is to apply Article 82. Various tests exist for determining dominance within the market. These include identifying the market share of the undertaking and of competitors, examining the financial and technical resources at the undertakings disposal, analysing the ability of undertakings to control production and distribution and examining the actual conduct and performance of an undertaking (Kent 2001: 256).

Having defined the market in order to determine dominance, the Commission must then identify whether an undertaking has abused its dominant position. Abuse essentially refers to conduct which influences the structure of a market in a way which weakens competition. Article 82 provides guidance as to the types of agreement that might be considered abusive. As with Article 81, the abuse must affect trade between member states.

The procedures available to the Commission for the enforcement of Article 81 and 82 are contained in Regulation 17/62. The Commission has 
wide powers of investigation and has the ability to fine undertakings up to 1 million euros or 10 per cent of the undertaking's global turnover - whichever is greater. Decisions of the Commission are reviewable before the CFI and on further appeal the ECJ. Alternatively, complainants can bypass the public enforcement procedures of the Commission and rely on private enforcement before national courts to challenge alleged anti-competitive practice. As the Commission proposal to amend competition law procedures outlined above illustrates, the Commission is keen to extend the use of private enforcement. However, as is examined below, the proposal to also devolve the exemption procedures outlined in Article 81(3) to national authorities raises important questions concerning the future definition of the separate territories concept for sport.

\section{Sport and competition law}

The discussion of the above general principles of competition policy gives rise to more specific questions concerning the applicability of such principles to sport. A number of questions arise in relation to the applicability of Article 81.

First, are sports organisations considered 'undertakings'? Amateur and professional sports organisations and individuals will be considered undertakings if they are engaged in economic or commercial activity involving the provision of goods and services even if this activity generates little profit or indeed their activity is not for profit. On first appearance, sports organisations are primarily concerned with regulating sporting conduct. Rules concerning the operation of the off-side rule in football are clearly of sporting interest only. However, sports organisations have a wider responsibility to ensure the commercial success of their sport. Frequently, international federations gather receipts from national associations and are centrally involved in a range of economic activities including exploiting broadcasting and sponsorship rights. National associations also have a responsibility for marketing broadcasting rights on behalf of participants. Similarly, clubs are to be considered commercial undertakings. Such commercial activity ranges from ticket sales to transfer dealings. In some cases clubs are quoted on the stock exchange in the form of public limited companies. Finally, players are paid for their services. Some football clubs are prepared to pay large sums to secure the services of the better players. This desire to attract the best not only improves sporting performance, it also contributes to the commercial potential of a club. Given that this activity need not generate profit, it is clear that sports organisations should be considered undertakings.

Second, do sports rules constitute 'agreements'? Given the broad definition of agreements employed by the Commission and the ECJ, it is of little doubt that rules relating to, for example, the transfer of players are agreements by undertakings or associations of undertakings. The relevant 
strength of the international federation must be taken into account when deciding whether an agreement has been reached between undertakings (such as clubs) or by an association of undertakings (such as the international federation). Organisations such as FIFA and UEFA have statutes whose nature clearly indicates regulatory strength. However, not all rules contained in these statutes are commercially based. The difficulty for the Commission lies in distinguishing between rules which are inherent to the sport and rules which have commercial implications. The distinction is not always clear-cut. Furthermore, the Commission need not be convinced by the assertion by sports organisations that the object of a particular rule was sporting in nature as they can examine the effect of this rule. Rules which initially were designed for sporting reasons may have assumed greater economic importance due to developments in the sector (Pons 1999: 7). Therefore sporting rules having commercial implications can still be caught within the scope of competition law.

Third, do sports rules have the potential to prevent, restrict or distort competition in the EU? Rules which have a minor impact on competition are not subject to EU competition law. Nevertheless, as in any other sector, horizontal and vertical sporting agreements do have the potential to be caught within the scope of competition law. Of course competition in the sports sector is not necessarily the same as in other sectors due to the unique interdependence within the sector. This leads to a supplementary question concerning the overall place of sport within competition law. The business of sport is different to other businesses in one important respect - participants in the sports market rely on each other for their success, they do not seek to eliminate competition. Oligopoly would not serve the interests of the remaining powerful participants who rely on competition to make the game in question interesting and unpredictable. Furthermore, in many sports, such as football, large clubs benefit from the available pool of talent cultivated by smaller clubs. The Commission is therefore faced with returning to the question of what constitutes a sports rule and what is a commercial rule. Case law is beginning to provide some answers to this question (see below).

Fourth, do sports rules affect trade between member states? Much European sport is based on a single structure model. An international federation controls the activities of the national associations who in turn regulate competition within their jurisdiction. It is clear therefore that many sports rules have international implications. This is most clearly demonstrated in relation to rules governing the transfer of players. Again, not all rules have international implications. Stevenage Borough's claim against the Football League failed because the League ruling preventing the club entering the Football League from the non-leagues did not affect trade between member states. ${ }^{8}$ Stevenage had argued that membership of the Football League would enable them to compete for a place in European competitions - a remote prospect (Beloff et al. 1999: 146). 
Finally, if the activities of sport are covered by Article 81, should sport qualify for an exemption under Article 81(3)? Individual agreements could be exempt or agreements pertaining to the wider sports sector could qualify for a block exemption. This issue is dealt with more fully below and in the concluding section of this text.

Much of the reasoning advanced above supporting the view that the activities of sport's organisations are subject to Article 81 also applies to Article 82. Nevertheless, further questions remain concerning the issue of dominance in sport. In particular, are sports organisations capable of assuming a position of dominance within the relevant market? The answer to this question lies in the definition of the market. Egger and Stix-Hackl argue that, although the relevant product market for sport differs from other sectors, a market (three altogether) still exists (Egger and Stix-Hackl 2002: 86). The first is the exploitation market in which clubs and federations exploit secondary features of their performances such as broadcasting rights, exclusive distribution systems for ticket sales and merchandising arrangements. The second is the contest market where the actual product, the sporting contest, is made. To stage an effective contest, rules regulating competition between participants and rules limiting access to sporting competitions are formed by sports governing bodies. The third market is the supply market where clubs buy and sell players.

A potential for a finding of dominance is enhanced due to a number of factors. First, the European model of sport necessitates international sports federations to assume considerable (even monopolistic) control over the activities of members. The 'market share' of organisations such as UEFA is therefore considerable. Potentially compounding this dominance is the restrictive rules often employed by governing bodies to maintain the single structure model. Clubs could also be regarded as having a dominant position should they co-ordinate their activities. It is less likely an individual club would be found to have a position of dominance although the definition of the relevant market may show otherwise. Second, if it is to be accepted that the sports market consists of three markets, undertakings operating within them are more likely to assume a position of dominance than if the market was defined in a wider sense. This links into the third reason - the potential for a finding of dominance is enhanced by the limited scope for demand- and supply-side substitutability in the sector. These issues are further developed in the review of case law below.

The definition of the geographical market flows from that of the product market. It is difficult to argue against the whole EU being considered the relevant geographical market for agreements concerning the sale of broadcasting rights, rules on international transfer and even ticketing arrangements for major international sporting events such as the football World Cup. Of course the finding of dominance is not in itself illegal. As such, the Commission must establish whether an abuse of this dominance has taken 
place. The development of Commission jurisprudence in this field is beginning to identify examples of abuse in the sports sector (see below).

The case law of the ECJ and Commission confirms sport's relationship with EU law. The Walrave and Donà cases established that sport is subject to EU law whenever practiced as an economic activity. Nevertheless in the immediate aftermath of these rulings, the Commission did little to enforce the central findings. As a result, throughout the 1970s and 1980s, the Commission took little interest in the operation of sport. At that time the Commission was not best placed to apply the competition implications of these rulings due to its own status and indeed the status of sport. A number of factors changed this.

First, it was not until the maturation of the Directorate General for Competition Policy in the 1980s that the link between sport and competition law became more likely. Second, this maturation coincided with an accelerated push to complete the Single Market. The powerful logic of negative integration served to enmesh new economic sectors within the Single Market. Third, sport began to practice as a truly economic activity in the late 1980s/early 1990s. This coincided with an influx of money into sport, especially football, partly as a consequence of technological advances in broadcasting. Fourth, the ruling in Bosman served as an important watershed in the thinking of Commission officials and served to confirm sport's status as an economic activity subject to EU law. Whilst the ECJ chose to apply Article 39 to the case, the Commission exploited the competition dimension of the case in order to fully enforce the ECJ's central findings.

Following Bosman, rules devised by European sports bodies in order to maintain a competitive balance between participants were increasingly attracting the regulatory interest of the Commission. Given the broad definition of anti-competitive behaviour adopted by the Commission and ECJ, it is clear to see the ease by which sporting rules, many of which were devised in an amateur age, may infringe competition law whenever sport is practised as an economic activity within the meaning of Article 2 of the Treaty. Sporting self-regulation has thus become increasingly challenged from above and below. From below, individual complainants frustrated by the lack of redress within sporting circles used the Commission and the ECJ as a new legal venue. From above, the EU institutions, keen to extend legal rights to all EU citizens, including sports men and women, accommodated such complaints. The Commission has investigated cases relating to the operation of sport in each of the three product markets identified above.

\section{The exploitation market: the marketing of sport}

The broadcasting of sport

Sport, and in particular football, has become of critical importance to broadcasters. In Britain, sports broadcasting has been the cornerstone of BSkyB's 
success and the reason for the failure of ITV Digital. Whilst BSkyB prospered following the conclusion of successive contracts to broadcast English Premiership games, ITV digital went into administration and returned its broadcasting licence following the signing in 2000 of the $£ 315$ million contract to broadcast lower league games in England, a contract left unfulfilled and ultimately re-negotiated by BSkyB. ${ }^{9}$ Just as sport is of critical importance to broadcasters, so the exploitation of broadcasting rights is a major source of revenue for sports clubs, national associations and international federations. Agreements concluded between sports organisations and broadcasters must, in general, comply with Article 81 . As such, the Commission has become centrally involved in questions relating to how these rights are exploited.

The precise relationship between sports broadcasting and competition law will depend on the definition of the market. Although the geographical broadcasting market is normally considered national due to linguistic and cultural factors, the universal appeal of sport indicates that a wider geographical market exists. The product market is more complex. Beloff et al. identify three issues relevant to the definition of this market (Beloff $e t$ al. 1999: 150). First, the market needs dividing into pay-TV and free-to-air broadcasters. In this sense sport is more substitutable on free-to-air television than it is on pay-TV due to the direct relationship between viewing sport and the money paid to watch it.

Second an analysis needs making of the market relevant to the sport in question. Do separate markets exist for separate sports? It is traditionally argued that football should be considered a market separate from other sports. The contrasting fortunes of BSkyB and ITV Digital point to arguments on both sides. Whereas BSkyB's experiment with pay-per-view broadcasting of Premiership matches has proved satisfactory, ITV Digital's attempt to do the same with lower league football was disastrous. The substitutability of football therefore varies. Only top-flight football and perhaps major boxing encounters can truly be considered a separate market from other sports. Such questions are becoming more significant in the new world of multi-channel specialist television.

Third, do separate markets exist in the broadcasting of live sport and recorded sport? The picture once again varies. In the Netherlands, the competition authority has argued that a separate market did exist for broadcasting highlights of sports events. One of the reasons for the failure of Dutch pay-TV channel Sport in 1997, which broadcast live football, was the availability of highlights on free-to-air television (Van Den Brink 2000a: 361-362). The non-substitutability of football in this instance was therefore questionable. However, as Beloff et al. explain in the case of Britain, 'BSkyB's success in using live football coverage to sell pay-TV subscriptions indicates that comprehensive highlights programmes such as Match of the Day do not constrain their pricing ability for live football' (Beloff et al. 1999: 152).

Although any aspect of a broadcasting contract may fall within the scope 
of EU competition law, four particular themes have emerged in terms of the sports broadcasting cases to have come before the Commission. The first concerns the practice of collective selling of rights. The second relates to the sale of exclusive rights, a practice often linked to collective selling. The third theme is concerned with the nature in which rights are acquired and the fourth is how events are transmitted.

\section{Collective selling}

An established commercial practice in the European sports sector is the central marketing and joint sale of broadcasting rights on behalf of the participants. Participation in the league is often conditional on the acceptance of this practice. Accordingly there is little doubt that collective selling is to be considered an 'agreement' in the context of competition law. Collective selling is considered vital by sports organisations as it allows them to maximise revenues, thus enhancing their re-distributive capabilities.

National law will determine who owns the broadcasting rights in the first instance and national regulatory agencies have become involved in central marketing issues. For instance, in Germany, the Federal High Court (Bundesgerichtshof) concluded that the central marketing of European Cup football matches by the national football association was a cartel for which no exemption could be justified. ${ }^{10}$ This ruling has since been overturned by legislation with effect from 1 January 1999 due to the addition of section 31, dealing with sport, to the German Competition Act legislation. In Britain, the Restrictive Practices Court held that the $£ 743$ million 'bundled' contract between BSkyB and the BBC to show Premier League football was not in violation of the 1976 Restrictive Trade Practices Act. ${ }^{11}$

If inter-state trade in broadcasting services is affected, the Commission becomes the relevant regulatory agency. A number of competition concerns may stem from collective selling. First, does the prevention of clubs from entering into individual agreements with broadcasters amount to a restriction of competition and fall within the scope of Article 81(1)? If the central marketing of broadcasting rights is necessary to ensure the survival of the smaller participants in the league (the so-called solidarity argument) should an exemption under Article 81(3) be granted? Second, does collective selling affect competition between broadcasters by reducing the number of available rights on offer? Clearly if clubs could market their own rights more broadcasters could enter the market for them. This may have implications for the creation of a single European market in broadcasting. Finally, does collective selling constitute an abuse of a dominant position by the vendor? In this connection, leagues themselves can be considered undertakings. Given that sports clubs cannot realistically operate outside a league structure and a condition for league membership is the acceptance of broadcasting rules, it follows that a position of dominance on the part of the league can be deduced. Article 82 may therefore also be relevant. 
Collective selling in sport has only recently been addressed by the Commission. In the Deutscher Fubßball-Bund (DFB) case the German National Football Association has requested a negative clearance or an exemption from the application of Article 81 in respect of the collective sale of the television and radio broadcasting rights for professional football matches in Germany. ${ }^{12}$ The DFB organises football competitions in Germany and collectively sells the broadcasting rights to the games on behalf of the participants. The DFB redistributes the revenues gained from these broadcasting contracts back to the participants. The contracts in question concerned the rights to show first and second division Bundesliga games primarily on a free-to-air basis but with some provision for a limited number of games to be shown on a pay-TV basis. The DFB claims authority to enter into such contracts as chief organiser of the events. Furthermore, the DFB claim that central marketing performs an important solidarity function in German football in that money is redistributed fairly between participants. The pro-competitive effects of central marketing therefore outweighs the anti-competitive effects. At time of writing, the Commission has yet to form an opinion on this matter.

In the UEFA Champions League case, UEFA applied for a negative clearance or an exemption from Article 81 in respect of the central marketing of commercial rights to the UEFA Champions League. ${ }^{13}$ 'Commercial rights' refer to the television rights, sponsorship rights, supplier rights, licensing rights and intellectual property rights. UEFA organises the Champions League, a prestigious tournament involving teams finishing in the highest places of domestic leagues. UEFA centrally markets the broadcasting rights to these games on behalf of the participants and allocates most of the revenues to these teams (hence the financial importance for clubs to qualify for the Champions League). ${ }^{14}$ Smaller amounts are redistributed to grass roots football. The rights were sold as a bundle on an exclusive basis for up to four years to one broadcaster in each member state. Although the broadcaster is normally a free-to-air operator, they could sub-license some games to payTV operators. UEFA justified central marketing by claiming that without it there would be a diminution of the UEFA Champions League brand. This would have the effect of making the competition less visible and attractive and therefore have a consequential impact on sponsors, clubs, broadcasters and spectators. Furthermore, central marketing serves a solidarity function and hence enhances competition rather than restricts it.

In July 2001, the Commission opened proceedings against UEFA concerning the collective marketing of the television rights for the Champions League. ${ }^{15}$ In particular, the Commission objected to UEFA's practice of selling the rights exclusively to a single broadcaster in each state. It is the Commission's contention that this practice restricts competition in the market for such rights, as only larger operators are able to afford the rights. This may have a consequential impact on broadcasters and viewers. 
Less-established broadcasters are unable to penetrate the market. This may have the effect of slowing down the use of new technologies such as internet and mobile phone use. Furthermore, the Commission believes that viewers are denied wide access to televised matches. Due to the nature of the exclusive contracts, some live games remained unexploited therefore denying fans the ability to view live games. Other broadcasters (such as regional broadcasters or broadcasters embracing new technology) willing to broadcast these games were denied the opportunity by the exclusive contract. In the statement of objections the Commission made it clear that, although the final decision will be informed by the Nice Declaration on Sport, if less-restrictive means are available to secure UEFA's objectives, a negative clearance or an exemption will not be granted.

In light of the Commission's objections, UEFA re-worked their selling policy leading to a more favourable response from the Commission. ${ }^{16}$ In the revised plans from 2003/2004, UEFA retains the right to sell live television rights and highlights for a period of no more than three years. However, delayed television rights and new media rights will be co-exploited by UEFA and the clubs. In essence, the media rights are exploitable in 14 packages. For instance package 1 (the 'gold' package for broadcasting live games) sells the rights, including highlights, for the first and third pick of games on match day. Package 2 (the silver package) does the same for the second and fourth pick of games. These packages are to be sold by UEFA to free-to-air and/or pay-TV. In other packages involving less-attractive games, delayed transmission, archives and radio and internet broadcasting, the clubs are given greater freedom to exploit the rights. The Commission has agreed that UEFA's amendments will allow for new market opportunities for a wider number of operators, both broadcasters and clubs, and viewers will benefit by being able to view a larger number of games. The Commission has given its preliminary approval of the modified arrangements and has invited interested third parties to submit observations. This informal decision will be published in the Official Journal in the form of a notice. Should no further objections arise from the market-testing procedure, the Commission has committed itself to taking a formal decision in the form of an exemption under Article 81(3).

The significance of the Commission's approach lies in their (conditional) willingness to acknowledge the specificity of sport. In a Competition Policy Newsletter, the Commission stated,

the special characteristics of the sport in question have to be taken into account. These could include, for example, the need to ensure solidarity between weaker and stronger participants or the training of young players, which could only be achieved through redistribution of revenue from the sale of broadcasting rights. Such aims would have to be a genuine and material part of the objectives and ones which could not be achievable under less restrictive arrangements. (Commission of the European Communities 1998: 26) 
As such, the Commission has indicated that in some circumstances collective selling does have a place in sport. This view was confirmed in the Formula One investigation (see below) in which the Commission indicated that collective selling was appropriate due to the specific characteristics of motor sport and in particular Formula One. ${ }^{17}$

\section{Exclusivity}

Exclusivity is closely connected to collective selling. By denying a competitor access to broadcast a particular sporting event, the purchaser of the exclusive rights can maximise viewing figures thus helping the operator to either honour public service commitments or maximise advertising and/or subscription revenues. New subscription-based TV operators have increased competition in the broadcasting market and have undoubtedly served to increase the price of such rights through their subscription-based ability to bid high. Although this may have increased revenues for sporting organisations, free-to-air access to sporting events is limited. The Television Without Frontiers Directive is partly concerned with this issue of public access to sporting events. ${ }^{18}$ However, there are also competition policy considerations to be taken into account. Exclusivity may have market foreclosure implications by denying broadcasters the opportunity to develop commercially through the acquisition of rights. Given the importance of sport to new broadcasters, exclusivity may result in the stifling of attempts to establish a single European market in broadcasting.

Nevertheless, in previous case law concerning the granting of copyright licences the Commission and the ECJ have indicated that they are not opposed to exclusivity per se. ${ }^{19}$ However, the Commission will investigate such arrangements if they unduly restrict competition in the broadcasting sector. This is consistent with the Commission's desire to realise a free market in broadcasting requiring the reduction of barriers to market entry. The sale of exclusive broadcasting rights, sold on long-term contracts, may be viewed as one such barrier to market entry. The Commission believes that exclusive deals may be exempt from competition rules when they are granted for a brief time and are limited in their scope and effect. The market power of the buyer and seller must be taken into consideration as must the potential for market foreclosure. Long contracts may be acceptable if the purchaser is a new market entrant requiring a substantial contract to become established. Occasionally, new entrants invest heavily in new technology necessitating longer contracts in order to counterbalance the risk of market entry. An exemption under Article 81(3) may be granted in such circumstances. An exemption may be granted if exclusive rights are reasonably sublicensed, thus allowing wider access to the rights to other market players. However, 'sublicensing is not by itself either a satisfactory or a convenient way of solving the competition problems of sports broadcasting' (Commission of the European Communities 1998: 27). The cost of the 
sub-licensing and the nature of the material offered (edited/unedited for example) are considerations. The licensees must genuinely benefit from the arrangement.

The Commission is gathering more experience in these matters. The first example concerns the agreement between British Satellite Broadcasting (BSB), now British Sky Broadcasting (BSkyB) following a merger in 1990, and the English Football Association to show live English football matches between 1988 and 1993 to a subscription audience. ${ }^{20}$ The Commission exempted the agreement, even though the contract was for five years, because the Commission felt that as a new operator, embracing new technology, BSB needed a long-term contact to establish its operations. However, as (now former) Commissioner Van Miert announced in 1997, 'looking back ... the five year period approved by the Commission was probably too long because the broadcasting technique in question became established more rapidly than had been expected' (Van Miert 1997).

Van Miert's more hard-line stance on long exclusive contracts was demonstrated in KNVB case. ${ }^{21}$ On this occasion the Commission did not sanction what it regarded to be an anti-competitive agreement between the Dutch Football Association and Sport 7, a Dutch television channel. Under the terms of the agreement the KNVB granted Sport 7 exclusive rights to Dutch football over a seven-year period. The agreement was notified to the Commission in May 1996. The Commission objected on two counts. First, seven years was deemed to be excessively long for an exclusive contract that denied competitors broadcasting access. This could act as a potential barrier to entry for new operators in the market. Second, the Commission objected to a renewal clause in the contract that would have unfairly privileged Sport 7 in the tendering procedure at the end of the term.

\section{Collective purchasing}

The widely used system of collective selling and the high costs associated with the acquisition of exclusive rights has contributed to the practice of broadcasters grouping together to collectively purchase sports rights. Sports rights are often out of the financial reach of individual broadcasters. Collective purchasing agreements allow broadcasters to not only spread the cost of rights but also to share the risk for broadcasting events.

Collective purchasing is a tool employed by the European Broadcasting Union (EBU). In order to improve the collective bidding power of the public service broadcasters, the EBU was established in 1950. Since the trend towards the deregulation of the broadcasting market and the rise of new commercial operators in the 1980s, the work of the EBU has become more important to public service operators attempting to keep pace with the rising cost of broadcasting rights. Historically, membership of the EBU has only been open to broadcasters with a public service obligation. Commercial operators cannot join and the EBU has no commercial aim, although a few 
commercial operators have achieved membership due to 'various anomalies and historical accidents' (Collins 1994: 121). Based in Geneva and Brussels the EBU operates the Eurovision network of programme exchanges and acts as a collective purchasing agent for its members. This form of collaboration is clearly aimed at securing a competitive advantage for EBU members at the expense of commercial operators. However, with the evolution of a EU broadcasting and audio-visual policy, the activities of the EBU have become increasingly called into question (Humphreys 1996).

In both the Screensport v. EBU Members case and the EBU-Eurovision System case, the Commission identified a restriction of competition stemming from the EBU's collective purchasing arrangements. In the Screensport case the Commission refused to grant an exemption because the nature in which the EBU provided exclusive sports rights to Eurosport effectively foreclosed the market to Screensport, Eurosports main competitor. ${ }^{22}$ In the EBUEurovision System case concerning the EBU's Eurovision programme sharing arrangements, the Commission believed that once acquired, the EBU were unfairly denying non-EBU members access to sporting rights. In order to qualify for an exemption under Article 81(3) of the Treaty the Commission imposed strict sub-licensing conditions. ${ }^{23}$ The Commission decision was however annulled by the CFI following an appeal by a commercial broadcaster. ${ }^{24}$ The CFI considered that the Commission had not adequately considered the anti-competitive consequences of the EBU's membership rules when granting an exemption. The EBU subsequently amended their membership rules and the Commission formally approved the EBU-Eurovision system in May 2000. ${ }^{25}$ The exemption is granted until 31 December 2005.

In a further case concerning collective purchasing, the Commission raised objections to an agreement between Telefónica and Sogecable to exploit rights to broadcast football in Spain. The Commission was concerned that such collaboration could foreclose the market to cable and digital competitors of Telefónica and Sogecable. Following the issuing of a statement of objections to Telefónica and Sogecable in April 2000, improvements to the arrangements were made by the two parties. ${ }^{26}$

\section{Broadcasting restrictions}

UEFA not only has responsibility for marketing broadcasting rights, it also controls the cross-border transmission of football matches through the provisions of Article 14 of its Statute. ${ }^{27}$ The reason for this is that UEFA fears that attendances at 'live' matches and indeed participation at all levels, would be adversely affected by broadcasting matches played at the same time. Since being introduced in 1988, UEFA's broadcasting regulations have however been challenged by various broadcasters. The Commission's investigations into them have centred on their compatibility with Article 81 of the Treaty. The cross-border trade in the broadcasting of football matches 
between member states could be restricted by their application. In addition, the regulations prevent national football federations from freely marketing their transmission rights in the Single Market. As a result of Commission scrutiny and after consultations between UEFA and the Commission, the broadcasting regulations have been amended, first in 1993 and most recently July 2000 following the 1998 issuing of a statement of objections by the Commission outlining the breach of Article 81. In April 2001, the Commission decided that UEFA's new rules on the broadcasting of football matches as amended in July 2000 fall outside the scope of EU competition rules as no appreciable restriction of competition could be identified and neither was inter-state trade appreciably affected by these arrangements. The rules allow national football associations to block the broadcasting on television of football during two and a half hours either on Saturday or Sunday to protect stadium attendance and amateur participation in the sport. The Commission closed the case with a formal decision in April 2001.28

\section{Ticketing arrangements}

Ticketing arrangements for major sporting events arguably falls between the exploitation market and the contest market. On the one hand ticketing is a method of marketing the game whereas on the other it is an essential component of organising the competition. As ticketing arrangements for major sporting events are linked to exclusive distribution networks, it is dealt here within the context of the exploitation market. It has become an established commercial practice for the organising committees of sporting events to enter into agreements with ticket distributors, guaranteeing for the distributor, often for a high price, the exclusive right to distribute the tickets within each of the member states. Rather than being one single market for ticket sales in the EU, nationally tied exclusive agreements create fifteen different markets (based on EU15). Very often, only residents of the country in which the exclusive ticket distributor is based can purchase tickets. In effect, therefore, each country is given a ticket quota which the exclusive distributor then sells to the public. The alleged benefit of this system is two-fold. First, it guarantees a fair and equitable distribution of tickets to fans of all countries, large and small, who want to purchase tickets. Second, it ensures spectator separation along national lines. This is considered an important safety feature.

The ticket distribution system for the 1990 World Cup finals held in Italy was investigated by the Commission, the first example of Commission involvement in ticketing arrangements for sporting events. ${ }^{29}$ In November 1989, the Commission received a complaint from travel agent Pauwels Travel against the FIFA Local Organising Committee Italia '90, 90 Tour Italia SpA and NV CIT Belgique. In this case, the organising committee of the World Cup entered into agreements with a range of tour operators guaranteeing them the exclusive right to sell tickets within the country they were 
based. Pauwels Travel wanted to put together and sell a package deal for Belgian fans wishing to travel and stay in Italy and also to gain entrance to the stadiums. However, Pauwels was not the exclusive tour operator authorised to sell package deals in Belgium. When Pauwels attempted to purchase tickets by other sources, the authorised agent in Belgium initiated legal action against them before the Belgian courts. The Commission objected to this arrangement arguing that it contravened Article 81(1). The use of exclusive agents effectively foreclosed the market to other travel agents. No fine was imposed on the organisers as the offence was the first of its kind to be investigated by the Commission and the Commission noted that ensuring spectator separation and hence safety was a legitimate aim. As such, the decision did not establish a free market for tickets. It simply prohibited exclusive arrangements from being disproportionately restrictive.

The most high-profile Commission investigation into ticketing arrangements for a major sports tournament came with France '98 World Cup case. After being chosen as host for the 1998 World Cup Finals in July 1992, the French World Cup organising committee, the Comite Français d'Organisation (CFO), began consultations in 1994 on the mechanism by which the 2,666,500 available tickets were to be distributed (Weatherill 2000a). Most of the tickets were distributed amongst national football federations, official tour operators and sponsors, although 749,700 were distributed by the CFO to the public. These tickets were only available to those with a French address.

The CFO gained approval from the Commission for its distribution system in June 1997. The Commission claim that at this time they were unaware of the nationality requirement even though the CFO had informed the Commission of the details outside the scope of the official notification and the France '98 web-site had been opened since May 1997. Furthermore, in June, prior to the clearance, the Commission received a complaint regarding the discriminatory arrangements (Weatherill 2000a: 278). Nevertheless, the consequence of withholding a percentage of the tickets exclusively for the French market soon became clear as football federations, fans and even some governments complained that the distribution system had discriminated against non-French fans resulting in insufficient tickets being available to foreign fans. The Commission's response was to issue a warning letter to the CFO on 20 February 1998 requesting an adaptation of its sales policy. By that time only a small number of tickets remained. The basis of the request was that the ticket distribution system adopted by the CFO had breached Article 82 of the Treaty dealing with abuse of a dominant position. In a news release on 23 March the CFO made clear it was prepared only to distribute 50,000 of the 160,000 remaining tickets to the foreign federations with the other 110,000 being sold directly by the CFO to citizens of the 15 EU states plus Norway, Iceland and Liechtenstein. ${ }^{30}$ These tickets went on sale in April. 
Articulating the concerns of many European football fans, 32 Members of the European Parliament (MEP's) and 41 Belgian football fans brought a case against the CFO before the Tribunal de Grande Instance in Paris (Corbett 1998). ${ }^{31}$ The basis for the complaint was that the distribution of World Cup tickets not only breached Article 82 of the Treaty but also breached Articles 12 (ex 6) and 49 (ex 59). Article 12 prohibits any measure within the scope of the Treaty that discriminates on the grounds of nationality. Article 49 prohibits restrictions on freedom to provide services within the EU. The case was considered as inadmissible by the French court and as such failed.

On 20 July the Commission issued a formal legal decision against the CFO. ${ }^{32}$ The Commission concluded that the CFO's discriminatory ticketing practises amounted to an abuse of a dominant position and as such were contrary to Article 82 of the EC Treaty (and Article 54 of the European Economic Area Agreement). Given the popularity of football and the large demand for tickets, the CFO had a dominant position with respect to distributing tickets. Not only were consumers unlikely to substitute the World Cup 'product' for another event, but the Commission found the relevant geographic market was the entire EU/EEA. Given such a dominant position the organisers should have ensured that they did not abuse this by instituting a discriminatory distribution system. The discrimination against non-French residents was reinforced by the $\mathrm{CFO}$ advising such people that tickets could only be obtained from national football federations and tour operators. As the ticketing arrangements were similar to those adopted in previous World Cups, the Commission chose to fine the CFO a symbolic sum of just 1,000 euros. In addition, the Commission acknowledged that the CFO did not have case law guidelines to guide them in their decision to establish such a system. Also, the Commission noted that the CFO had been co-operative and had made more tickets available to non-French customers. In the formal decision, the Commission concluded that future breaches of EU competition law in relation to ticketing arrangements would be dealt with more seriously.

\section{Merchandising}

EU case law on merchandising issues in sport is limited even though this activity is becoming an essential component of any sports organisations business strategy. Clubs, players and even competitions are considered marketable commodities. The growth in the market for replica club kits illustrates the merchandising potential of some sports. Generally, national laws concerning trademarks, passing-off and copyright apply to disputes arising from merchandising issues. Occasionally such laws have a EU dimension. For instance in Arsenal Football Club plc v. Matthew Reed, the ECJ has been requested by the High Court of Justice of England and Wales to decide whether or not non-trademark use can constitute infringement of the registered trademark rights. ${ }^{33}$ The Advocate General in the case concluded that 
Article 5(1)(a) of the First Council Directive 89/104/EEC of 21 December 1988 relating to trademarks allows the proprietor of a trademark to prevent it being used for commercial purposes by a third party, even if it is perceived as a badge of support, loyalty or affiliation to its proprietor. ${ }^{34}$ In a further (pending) case the ECJ is examining whether advertising restrictions at sports venues stemming from French law (the Loi Evin) are contrary to the principle of freedom of services. ${ }^{35}$

The question of the application of competition law to merchandising agreements in sport is equally nascent. As yet, the Commission has only raised specific objections to agreements in the field of product distribution and sponsorship. The Commission has established that the distribution of sporting goods falls within the scope of Article 81. Commission case law in this field concerns restrictions designed to protect exclusive distribution networks. In 1992 a fine was imposed on Dunlop Slazenger International and All Weather Sports for blocking exports of tennis balls to other EU countries in order to protect its sole distributors in those states. ${ }^{36}$ Similarly, in 1994, Tretorn was fined for a breach of Article 81(1) relating to an export ban Tretorn had placed on their exclusive distributors of tennis balls. ${ }^{37}$ Both cases illustrate the Commission's desire to ensure fair competition between the manufacturers of sports goods and the protection of consumer choice.

Sponsorship arrangements have also been investigated by the Commission. Sponsors are prepared to pay the organisers of sports events significant sums to use the term 'official' (such as 'official ball') in competitions. One example of a Commission investigation into this practice is the Danish Tennis Federation (DTF) case. ${ }^{38}$ The DTF entered into agreements with three tennis ball manufacturers which resulted in their make of ball being labelled 'official'. A parallel importer complained to the Commission about market foreclosure. Furthermore, the Commission thought that the term official was misleading for consumers who may assume that the term represents a badge of quality rather than an indication of sponsorship. This was considered inappropriate for items such as tennis balls. Following negotiations between the DTF and the Commission amendments were made to the sponsorship arrangements for tennis competitions in Denmark. Under the new arrangement a more open tendering process is held every two years to decide sponsorship. The term 'official' has also been replaced by 'sponsor'. The case was closed by negative clearance. ${ }^{39}$

Given the commercial importance of marketing in sport, the competition case law is expected to expand. In protecting the rights of market competitors and consumers, the Commission will once again need to distinguish between commercial rules and sporting rules. Rules placing restrictions on sports equipment may for instance be justified. Technological advances in the manufacture of sports equipment can result in the games in question becoming too easy, boring or even dangerous. Technical restrictions on 
equipment is essential for all sports. Such rules cannot, however, act as a mask for the maintenance of anti-competitive rules.

\section{The contest market: organising the game}

Traditionally, sports organisations have operated a system of self-regulation. They have, by and large, remained free to determine the structural and organisational issues surrounding their existence. After all, for sport to be entertaining it needs to be highly organised and restrictions need to be placed on who competes in the sports sector. However, the commercialisation of sport has contributed to the erosion of this autonomy and has served to increase the penetration of EU competition law into sport. Furthermore, as has been established above, the definition of an economic undertaking adopted by the EU institutions is wide. Sports organisations at all levels are commercially active. Restrictions placed on their sporting freedom also affect their commercial freedom. Competition law may therefore have relevance for organisational issues in sport, although once again it must carefully distinguish between justifiable sporting restrictions and unjustifiable commercial restrictions.

\section{Maintaining the single structure model of sport}

The first category of competition law interventions concerns the maintenance of the traditional single structure model of sport. Most sport in Europe is organised on this basis. One international federation (in the case of European football, UEFA) controls the activities of its constituent members (single structure national associations such as the English Football Association). UEFA is one regional federation affiliated to the world's governing body FIFA. The federations expect affiliates to participate only in competitions organised by the federations. Single structure arrangements are however by no means universal in sport. Boxing, for example, is organised by a range of bodies. For the EU, the main areas of interest are two-fold. First, the Commission must decide whether restrictive practices employed by federations to maintain the single structure organisation of sport are to be tolerated. Second, if alternative or 'breakaway' structures are established, how best to regulate competition between them. The Commission has been asked to investigate the conduct of competing sporting federations. One of the first cases was a jurisdictional dispute concerning an indoor football league in Belgium. In 1994, the Commission rejected the complaint in question on the grounds that intra-Community trade was not seriously affected (Coopers and Lybrand 1995: 78).

In a similar, but much more high profile case in 1998, Media Partners International Limited, an Italian marketing firm, complained to the Commission about rules adopted by UEFA designed to prevent the establishment of a breakaway league. Media Partners notified the Commission of 
their intention to establish a new European Football League, independent of UEFA. ${ }^{40}$ The new 'super-league' was to consist of 18 founder clubs who would be given three years exclusive participation - a break from the traditional merit-based open model of promotion and relegation practiced in Europe. Other clubs would have to qualify. Those clubs with the largest potential to attract television viewers were invited to become founder members. To entice club participation, Media Partners offered a very large financial inducement totalling $£ 1.2$ billion to the participants (Van den Brink 2000a: 365). UEFA rules designed to prevent the establishment of alternative competitions by placing heavy sanctions on participants amounted, it was claimed, to an abuse of a dominant position (Ratliff 1998: 5). ${ }^{41}$ The Commission must decide whether it is acceptable to require clubs to leave their national leagues if they participate in an alternative pan-European breakaway league. A precedent exists which may guide Commission action in this area. In the Danish Co-operatives case, an agricultural co-operative was permitted to prohibit their members from participating in alternative agricultural co-operatives as the restriction benefited competition..$^{42}$ Sport could therefore claim that ancillary restrictions such as UEFA's rule is imperative to the effective operation of the competition in question (Van Den Brink 2000b: 421).

Even if competition law could be relied on to break open UEFA's organisational monopoly, the Media Partners proposal or any future similar proposal would still require Commission approval. It is questionable that any proposal seeking to challenge the single structure model of sport in Europe would pass Commission scrutiny unless the proposal maintains a competitive balance between all participants, large and small. This would require the new organisers to demonstrate a commitment to solidarity within the sport. Should the single structure model be broken, it is unclear to see why, other than to satisfy the Commission, the new league based on commercial imperatives would wish to promote solidarity outside the league it organises. Further questions remain concerning the establishment of a breakaway league. First, should entrance to a new league be based on founder members being granted exclusive participation for three years as Media Partners proposed, Article 81(1) could potentially be relied on as this would foreclose the market to new entrants. Second, are clubs who enter into an agreement to form a new league colluding in the market place, contrary to the provisions of Article 81(1)? Such parallel conduct can amount to a concerted practice and can arguably also be considered an abuse of a dominant position given that the new league would be composed of Europe's top clubs.

In the event, UEFA proposed a counter-measure resulting in the Football Champions League being revamped to accommodate the views of the majority of Europe's top clubs. As the top clubs accepted UEFA's proposal, the Media Partners proposal collapsed. 


\section{Multiple club ownership}

The second category of competition law interventions concerns the related issue of multiple club ownership. It is becoming common for media companies to seek to own a share in some of Europe's football clubs. In Italy for instance media companies own a share or control AC Milan, Fiorentina, Lazio, Parma and Roma. In Britain, media companies own a stake in Manchester United, Leeds United, Sunderland, Chelsea, Manchester City (all BSkyB), Newcastle United, Aston Villa and Middlesborough (NTL) and Liverpool (Granada). A similar picture is emerging across Europe, although in Britain the Competition Commission recommended the prohibition of the proposed total merger between Manchester United and BSkyB. Concerned at the possible impact on the integrity of its European competitions, UEFA passed a new rule on club ownership in May 1998. In the new rule notified to the Commission for a negative clearance or exemption, UEFA proposed that: (1) no club should have a financial or management interest in another club which participates in the same UEFA competition, (2) no person should be involved in the management of more than one club participating in the same UEFA competition and (3) no person or company may control more than one club participating in the same UEFA competition. UEFA was particularly concerned about contrived results and strategic player transfers although the Financial Times also noted that UEFA was worried that multiple club ownership could lead to a challenge to their monopoly over European football (Financial Times 1999b). Two football clubs owned by the English National Investment Company (ENIC) appealed to the Court of Arbitration for Sports (CAS) for the rule to be overturned. The clubs in question, AEK Athens and Slavia Prague had qualified for the UEFA Cup Winners Cup along with Vicenza, an Italian club also owned by ENIC. By the terms of the new UEFA rule, only one team could participate in the competition. In August 1999 CAS found in UEFA's favour. $^{43}$

ENIC subsequently lodged a compliant with the Commission in February 2000 arguing that the rule restricted competition. The Commission's own examination of UEFA's multiple owner rule was concluded in July 2002 with the formal rejection of ENIC's complaint. ${ }^{44}$ The Commission found that UEFA's rule is a decision taken by an association of undertakings and as such is theoretically caught within the scope of Article 81. However, the Commission agreed with UEFA that the rule was a sporting rule and was essential in order to maintain the integrity of competition. Although the object of the rule was not to restrict competition, arguably that was its effect. Nevertheless, the Commission concluded that the rule was proportionate in that it did not go beyond what was necessary to secure UEFA's chief objective concerning the integrity of its competitions and it was applied in a nondiscriminatory manner. 


\section{Club relocation}

The issue of club relocation is the third category to have appeared on the Commission's competition policy agenda. The tension between the commercial and socio-cultural dimensions of football has been highlighted by the Wimbledon, Clydebank and Mouscron cases. Both Wimbledon and Clydebank were reported to have considered asking the Commission to test rules preventing cross-border relocation against EU competition law (Duff 1998: 54). The Mouscron case concerned Belgian football club Excelsior Mouscron's request to stage the home leg of a UEFA Cup tie against French side F.C Metz in a nearby Stadium just across the border in Lille, France. UEFA imposed restrictions on Mouscrons ground limiting the normal capacity of 10,000 to just 4,500 and Mouscron argued that, due to the nature of the fixture, they required a larger stadium. UEFA blocked the move arguing that the home-and-away structure of its competitions needed protecting. UEFA maintained that the tie must go ahead in the stadium of the home host (Financial Times 1999a). This rule led two public bodies representing Lille and Mouscron to formally complain to the Commission. The Commission rejected the complaint made against UEFA by arguing that, 'the UEFA Cup rule to the effect that each club must play its home match at its own ground is a sports rule that does not fall within the scope of the Treaty's competition rules'. ${ }^{45}$ As such the case contains no EU interest.

\section{Formula One}

The most high-profile investigation conducted by the Commission concerns the organisation of Formula One motor racing. Not only did the Commission investigate the regulatory role of the sports governing body, it also examined issues relating to the commercial exploitation of broadcasting rights. For the sake of completeness both are considered in this section even though the broadcasting provisions should be read within the context of the discussion on the exploitation market.

In September 1997, AETV, a German television company complained to the Commission arguing that the Fédération Internationale de L'Automobile (FIA) had abused a dominant market position by controlling the broadcasting of motor sport. ${ }^{46}$ This complaint was followed in November 1997 by a second complaint, this time by the BPR organisation (known later as GTR). BPR claimed that it was forced out of business by the FIA's regulatory dominance in motor sport. BPR withdrew its complaint following a financial settlement. On the basis of these complaints, the Commission launched an investigation into the activities of the FIA. The Commission drew a preliminary conclusion that Articles 81 and 82 of the EC Treaty were being infringed.

In June 1999 the Commission opened formal proceedings into the commercial practises employed by Formula One and other international motor racing series. In particular, the Commission argued that the FIA has abused 
its dominant position and has restricted competition. The Commission also communicated this opinion to Formula One Administration Ltd (FOA) and International Sportsworld Communicators (ISC). The FIA organises international motor racing, FOA sells the Formula One television rights and ISC markets broadcasting rights to a number of major international motor sport events.

The Commission identified four competition issues relating to the operation of Formula One. ${ }^{47}$ First, the Commission believed that the FIA uses its power to block series which compete with its own events. As the FIA has sole regulatory control over motor racing in Europe, it controls the licensing of participants. The Commission believes that the FIA has used this regulatory dominance to restrict FIA licensees from participating in non-FIA competitions. Track owners, vehicle manufactures, organisers and drivers can be stripped of their license if they participate in non-FIA events.

Second, the Commission claimed that the FIA has used this power to force a competing series out of the market. To support this claim the Commission has argued that a competing promoter, the GTR Organisation, was eliminated from the motor racing market because of the FIA's regulatory dominance. The GTR's series was then replaced with a FIA championship. The Commission believes this amounts to an abuse of a dominant position.

Third, the Commission holds the opinion that the FIA uses its power to acquire all the television rights to international motor sports events. In 1995, the FIA introduced a rule stating that it owned the television rights to all motor sport it authorised. These rights were then transferred to ISC, a company owned by Bernie Ecclestone, also an FIA Vice-President. This means that ISC gains the television rights to all competitions authorised by the FIA. Although these rules were modified in 1998 the Commission still views this as an abuse of a dominant position. Formula One rights are dealt with under a separate agreement (the Concorde Agreement). However, the Commission believes that the effect is the same in that the FIA's dominant position effectively forces rights to be transferred to it. The rights are then transferred to FOA, another company controlled by Bernie Ecclestone. If the FIA acquired the rights abusively, then neither ISC or FOA can be said to have acquired the rights validly.

Fourth, the Commission also believes that FOA and the FIA protect the Formula One Championship from competition by tying up everything that is needed to stage a rival championship. In particular the Commission has identified three examples of attempts to foreclose the market to competition. First, the promoter's contracts prevent circuits used for Formula One races from being used for races that could compete with Formula One. Second, the 'Concorde Agreement' prevents Formula One teams from racing in any other series comparable to Formula One for a very long period of time. Third, the agreements with broadcasters place a massive financial penalty on them, ranging from between 33 per cent and 50 per cent of the price paid, if 
they televise anything deemed by FOA to be a competitive threat to Formula One.

Despite maintaining objections to the Commission's analysis, the FIA and FOA amended their internal rules in January 2001 leading to the publication of a notice in June 2001 indicating that the Commission took a positive view of the proposed changes. ${ }^{48}$ The essentials of the changes agreed by FIA and FOA include:

1 FIA has amended its regulations to strengthen the rights of motor sport organisers, circuit owners and participants, and to make it clear that FIA will act impartially as between all forms of motor sport for which it is the regulator.

2 FIA will no longer have a commercial interest in the success of Formula One and the new rules will remove any obstacle to other motor sports series competing with Formula One.

3 FIA will retain its rights over its championships and the use of the 'FIA' name and Trade Marks but has removed from its rules any claim over the broadcasting rights to events that it authorises and has agreed to waive any claim to broadcasting rights under the relevant clauses in the Formula One agreement (the 'Concorde Agreement').

4 FIA has made it clear that its decisions will always be reasoned, and that those decisions may be challenged before national courts.

5 The FOA group of companies has sold its interest in all forms of motor sport including Rallying and will therefore only have an interest in Formula One (Mr Ecclestone will no longer handle FIA's promotional affairs and will also reduce his role in FIA in other ways).

6 FOA has agreed to limit the duration of its free-to-air broadcasting contracts (to five years in the case of host broadcasters and three years in other cases) and has removed provisions which penalised broadcasters who wanted to broadcast other forms of open wheeler racing. ${ }^{49}$

These Commission enforced changes have had the effect of stripping the FIA of many of its commercial functions thus making the organisation essentially a sports regulatory body. By insisting on a separation between commercial rules and the rules of the game, the Commission has in effect sent a clear message to the sports world on how it practically intends to apply competition law to sporting situations. Given that no further objections were raised by third parties following publication of the notice, the Commission closed the case in October $2001 .{ }^{50}$ Privately, the FIA are 'delighted' with the settlement. $^{51}$

\section{State aid}

The issuing of state aid to sports clubs is an often overlooked aspect of EU competition law, although one highlighted by the European Parliament as early as $1994 . .^{52}$ State aid has the potential to affect competition between 
sporting participants and as such has relevance to the contest market. The Commission has formed an opinion concerning the granting of aid from the French government to professional sports clubs in France. ${ }^{53}$ The French government proposed granting a subsidy of up to 2.3 million euro per year to professional sports clubs with state-approved youth training centres. The Commission concluded that the aid was of an educational nature and not state aid. Article 87 of the Treaty prohibits aid granted by member states which distorts competition in trade between member states

\section{The supply market: the transfer system}

The supply market refers to the buying and selling of players. Transfer fees have traditionally been a common feature of European sport. For many years, football has operated a system whereby money is exchanged between clubs in order to secure the services of a player. The alleged benefit of transfer fees is that they compensate clubs for the training and development of players. Not only do transfer systems regulate the conduct between clubs, thus denying clubs from freely employing the services of workers they choose, they also impose restrictions on the ability of players to seek alternative employment at another club.

The Bosman ruling established that out of contract international transfer payments and nationality quotas were incompatible with Article 39. EU law therefore goes some way to protect the right of free movement for players in the EU. The rights of clubs to freely employ labour was not however guaranteed and some restrictions on players remained after Bosman. Although the ECJ did not answer the question concerning the compatibility of the international transfer system and nationality restrictions with EU competition law, the Commission held the view in the aftermath of Bosman that 'this is not a reason for not taking into account the application of the competition rules' (Commission of the European Communities 1996: 3). Amendments to the international transfer system made by FIFA/UEFA in light of the ruling in Bosman would therefore have to satisfy the Commission.

There can be little doubt that the functioning of international transfer rules is subject to scrutiny by the Commission. International football federations (such as FIFA and UEFA), national associations and clubs are considered undertakings as they are engaged in economic or commercial activity involving the provision of goods and services (see above). In the case of FIFA, UEFA and the national football associations, the label association of undertakings or grouping of associations of undertakings may be more appropriate (Egger and Stix-Hackl 2002: 85). The precise definition of such organisations matters little to the application of Article 81 as all are undertakings. The definition is only of importance when considering issues of liability. Furthermore the transfer system should be considered an agreement 
between undertakings or a decision of an association of undertakings in the case of FIFA's regulations. As is shown below, the regulations on transfer are contained within FIFA's constitution (statute). In addition, FIFA rules, whether binding on national associations or merely recommendations, are still caught by the scope of Article 81 .

Therefore, the transfer system clearly stems from an agreement of or between undertakings. As the rules on transfer stem from FIFA they are the relevant body to be investigated by the Commission. The Commission must then decide if the object or effect of such rules is the prevention, restriction or distortion of competition. Two issues are of relevance in this connection. First, transfer fees have the potential to restrict the clubs source of supply (i.e. players). This strengthens the market position of the large clubs at the expense of the smaller clubs who are unable to develop by attracting new and better players. This limits not only their sporting performance but also their commercial potential. Second, players are also disadvantaged by the transfer system. The requirement to pay a fee for a player has the effect of restricting that players wages and limiting his ability to find employment. Clearly, when assessing these effects, the Commission must examine the procompetitive effects of transfer fees. These are discussed below and a wider discussion on this matter is provided in the previous chapter.

The Commission must also identify whether transfer rules affect interstate trade. In all three relevant markets discussed above, football is a highly international game. As such, it is difficult to justify that transfer systems do not have a cross-border impact. Accordingly, the operation of the transfer system is caught by the provisions of Article 81 . The difficulty in applying Article 82 relates to the definition of the product market. It is the clubs and not the international federation who compete for the services of players and as such the relevant market is for players.

It is within the context of the above discussion that the Commission has conducted an investigation into transfer rules. In January 1996 the Commission notified FIFA and UEFA that is was launching an infringement procedure based on Article 81(1) against the continued use of their international transfer system and the $3+2$ restrictions on foreign players, a clear breach of the Bosman ruling. In this letter of notification the Commission informed FIFA and UEFA that following the ruling in Bosman, the international transfer system, as notified by FIFA/UEFA to the Commission on 28 July 1995, could not be exempt under Article 81(3) and Article 53(1) of the EEA Agreement. The Commission notified FIFA and UEFA that they must fully comply with Bosman within six weeks.

After failing to gain an exemption under Article 81(3), FIFA and UEFA informed the Commission that both the international transfer system and nationality restrictions would be abolished. In 1997 FIFA's new Regulations for the Status and Transfer of Players were adopted. Players would be able to move to another club in a different EU/EEA state at the end of their 
contract without a transfer fee being payable. Furthermore, in UEFA competitions, clubs were no longer restricted to fielding foreign players within the terms of the $3+2$ player rule.

Despite the abolition of the international transfer system and nationality restrictions by FIFA/UEFA, the Commission maintained an objection to certain aspects of the remaining transfer system. In June 1996, the Commission notified FIFA/UEFA that in their view Article 81(1) EC and Article 53(1) EEA had been breached by the requirement for payment of fees for international transfers within the EEA of players from third countries at the end of their contracts and the FIFA instruction to national associations in the EU/EEA to establish national transfer systems. On the issue of national transfer systems, the Commission drew the following conclusion:

The effect of national transfers is normally limited to one member state. However, one cannot exclude the possibility that continuing with national transfer systems may limit the freedom of clubs to hire the players that they want, or that their choice may be distorted by the maintenance of national transfers. One can, therefore conclude that in principle national transfer systems are also incompatible with Article 81 of the Treaty. (Commission of the European Communities 1996: 5)

FIFA and UEFA responded to the Commission's statement of objections by informing them that they did not intend to alter aspects of the transfer system not covered by the ruling in Bosman. The Commission informed FIFA/UEFA that given their reluctance to respond satisfactorily to the objections, formal infringement proceedings would be initiated. Little progress was made on the resolution of this issue although high-level talks did take place during the 1997 Amsterdam Summit on the social significance of sport. Although the subsequent Amsterdam Treaty only mentioned sport in a nonlegally binding Declaration, the involvement of the member states in sporting issues demonstrated that a school of thought within the EU had emerged which stressed the need to take the specific characteristics of sport into account in the application of EU law in sports-related cases. Despite this breakthrough for the sports world, the fact remained that sport was not granted an exemption by the new Treaty, the Commission still had obligations to act as the guardian of the legal framework of the EU and, furthermore, FIFA/UEFA had yet to satisfactorily address the Commission's objections.

Measures eventually proposed by FIFA/UEFA to alter the international transfer system failed to satisfy the Commission's objections. One measure proposed by UEFA's Executive Committee was the establishment of a standard player-club contract covering initially three years as a trainee and then three years as a professional under contract. UEFA recommended that national associations introduce this type of contract from July 1997. In the initial part of the contract, a transfer fee would still be payable at the end of 
the term. FIFA/UEFA notified the Commission of this proposal but the Commission took the preliminary view that the maintenance of the transfer system at the end of the initial part of the contract would render the standard contract as being incompatible with Article 39 of the Treaty. In a second proposal, FIFA Circular No. 616, paragraph 2 (adopted 4 June 1997) proposed the introduction of a system whereby the issue of an international transfer certificate could be refused if non-amateur players terminate their contract of employment before its date of expiry. Paragraph 1 of the Circular postponed until 1 April 1999 the abolition of the international transfer system within the EEA to non-EU players reaching the end of their contract. Both measures led to formal complaints being tabled to the Commission by three football clubs and players' organisations in Belgium.

Spurred by such complaints and frustrated by the attitude of FIFA/UEFA, on 15 December 1998, the Commission launched a formal investigation into the operation of the international transfer system. In the letter of objections sent to FIFA/UEFA, the Commission objected to certain provisions within the international transfer system which had the effect of:

1 prohibiting players from transferring to another club following their unilateral termination of contract, even if the player has complied with national law governing the penalties for breach of contract;

2 allowing a club to receive payment for a player leaving a club if the contract has been terminated by mutual consent;

3 encouraging high transfer fees which bear no relation to the training costs incurred by the club selling the player, a practice condemned by the Court in Bosman and one which limits the ability of small clubs to hire top players;

4 allowing for a transfer fee to be demanded for the transfer of players (both in and out of contract) from a non-EU country to a member state of the EU and vice versa.

The Commission indicated that the above points infringed Article 81(1) and no exemption could be justified. Point 4 also breached Article 81, although transfers from member state countries to non-EU states will only be caught by the scope of Article 81(1) if the club concerned plays regularly in competitions involving the participation of clubs from member countries. In essence therefore, the Commission held the view in the formal statement of objections that these provisions restrict the ability of clubs to recruit the players they want whilst also limiting the freedom of movement of players.

Once again the game's governing bodies were slow to respond the Commission's statement of objections. The Commission's response to FIFA/UEFA's inactivity came in the summer of 2000. Unless FIFA/UEFA submitted formal proposals to amend the international transfer system by 31 October 2000, the Commission would take unilateral action in the form of a formal decision to secure the changes necessary. 
Faced with the possibility of an end-of-year prohibition decision, FIFA and UEFA established a joint transfer task force chaired by Per Ravn Omdal, UEFA vice-president and member of the FIFA executive committee. Throughout September 2000, the task force examined potential amendments to the international transfer system in light of the Commission's objections. In this connection, they received support not only from many of Europe's top clubs, but also from the German Chancellor and British Prime Minister who in a joint statement expressed their support for the current transfer system. ${ }^{54}$

\section{The FIFA/UEFA Negotiation Document}

Despite their hostility, the joint FIFA/UEFA transfer task force produced a set a proposals that were duly submitted to the Commission by the imposed October deadline. The proposals were outlined in the form of a 'Negotiation Document'. ${ }^{55}$ In the introduction, FIFA/UEFA continued to question the validity of the Commission's complaints, although they did acknowledge that certain aspects of the transfer system needed revising. The document explained that a revised transfer system would need to ensure: (1) that contract stability was maintained, (2) that clubs were rewarded for the investment in the training of young players and (3) that the new system must ensure the redistribution of income which would help maintain a balance between the clubs. Using these principles as a starting point, the Negotiating Document outlined the following proposed changes to the international transfer system.

Prohibition of the international transfer of minors FIFA/UEFA justified this move in order to avoid the economic exploitation of minors, although this restriction would not apply to instances involving the relocation of the player's family to another state.

Training compensation for young players Concerned at the deleterious effect the abolition of transfer fees would have on the grass roots of football, FIFA/UEFA proposed the maintenance of fees for the transfer of players up to the age of 23 , even if the player had come to the end of their contract with the club. FIFA/ UEFA also noted that training compensation would be financed through 'solidarity mechanisms' such as a levy on transfer fees and a solidarity fund financed by income generated from the central marketing of television rights.

Respect for contracts FIFA/UEFA considered contract stability as an essential part of professional football not only in terms of team building and fan association with a club but also in terms of employment security for players. As a consequence, the Negotiation Document proposed that 
contracts lasting up to three years should be respected by both club and player. A maximum contract of five years was proposed.

Transfer periods For the purposes of maintaining contract stability and protecting the integrity of sporting competition, FIFA/UEFA proposed the introduction of two unified transfer periods with players restricted to one move per season.

An arbitration system The Negotiation Document proposed the establishment of a new voluntary arbitration system for the resolution of breach of contract disputes. Compensation payments would be agreed by the arbitration board in accordance with national labour laws. However, in order to respect the 'specificity of sport', sporting sanctions could be imposed on players breaching contract or for reasons of other 'unethical behaviour'. If the buying and selling clubs and the player agreed to a transfer fee, the use of the arbitration board would not be required and hence sporting sanctions not imposed. Although the Negotiation Document stressed that the arbitration system was designed for the international transfer system, it could act as a model for national transfer regimes.

Transitional arrangements The Negotiation Document stressed that a minimum necessity for the world of football is that alterations made to the transfer system protect existing contractual arrangements between clubs and players.

Following the submission of the revised transfer plans, negotiations between FIFA/UEFA and the Commission on the acceptability of the proposals were influenced by three key developments. The first was the rejection of the Negotiation Document by FIFPro, the international football player's union. The second was a tactical dispute between FIFA and UEFA and the third was the discussion of sport at the December 2000 Nice European Council.

\section{FIFPro's objections}

Despite being originally involved in the preparation of the FIFA/UEFA Negotiation Document, FIFPro, the international football player's union, failed to support the position taken by FIFA/UEFA within it. ${ }^{56}$ FIFPro's objections to the Negotiation Document, outlined in an alternative submission to the Commission, were essential two-fold (FIFPro 2001).

The first issue related to the rights of players to seek alternative employment at another club without undue restriction (FIFPro 2001: 6 and 13). In this connection, FIFPro share the concerns of the Commission in relation to the inability of players to unilaterally break a contract of employment with a club and move freely to another once compensation for breach of contract 
has been paid in accordance with national labour law. In the alternative submission, FIFPro questioned the alleged benefits of this system of player restraint. FIFA/UEFA claim that the restraint is needed in order to ensure contract stability (point 3 of the Negotiation Document). FIFPro argued that in the period between 1996/1997 and 1999/2000 both player mobility and transfer spending have greatly increased. ${ }^{57}$ This is because the maintenance of transfer fees gives clubs an incentive to sell contracted players. As such 'stability of contract, therefore, cannot be seriously seen as a positive symptom of the transfer system' (FIFPro 2001). Consequently, the abolition of transfer fees would eliminate this distortion and grant footballers equal rights of freedom of movement enjoyed by other economically active European citizens.

The second main objection forwarded by FIFPro concerned the related issue of the transfer system and the law (FIFPro 2001: 6). Although FIFPro agreed with FIFA/UEFA that a balance between clubs needed maintaining and clubs should be encouraged to recruit and train juniors, they argued that less-restrictive means than the transfer system can achieve these objectives. Whereas the FIFA/UEFA Negotiation Document stressed the economic importance of the transfer system for small clubs, the FIFPro report claimed that the distribution of income within football was in decline, primarily as a result of the income generated by the sale of broadcasting rights. Similarly, FIFA/UEFA claimed that the maintenance of the transfer system was required in order to encourage clubs to recruit and train juniors. The FIFPro report found no evidence to support this link, instead pointing out that due to transfer fee inflation, most top clubs have invested heavily in youth academies in order to develop their own juniors. FIFPro pointed out that FIFA/UEFA recognise the growing polarisation between rich and poor in European football yet are misguided to believe that the maintenance of the transfer system is required to prevent the gap growing further. FIFPro therefore questioned the validity of maintaining a system which is anticompetitive and restricts the freedom of movement of players, particularly given that it does not fulfil the objective of redistribution and training incentive stated by FIFA/UEFA.

In essence, FIFPro did not support the FIFA/UEFA Negotiation Document because they identified a hidden agenda implicit within it. This agenda sought not only to protect the transfer system, a system used by the game's governing bodies to 'restrain players' earnings and bargaining power', but also to enhance it and impose on players restraints more onerous than previously existed (FIFPro 2001: 6). In the case of young players (under 23) the FIFA/UEFA proposals could lead to a situation in which a player, having come to the end of his contract, could not leave a club without a transfer fee being paid. This, FIFPro argued, is a return to the pre-Bosman days of player restraint and as such a retrograde move. In the case of older players, the imposition of sporting sanctions for breach of 
contract also represents a restraint, particularly if the player has complied with national labour laws governing breach of contract. Furthermore, the FIFPro report claimed that the formula for calculating compensation fees imposes a fixed fee that bears no relation between the amount of costs actually used in the training of a player and the fee to be paid. 'History shows that such fees operate as a significant and sometimes definitive restraint that cannot only seriously undermine player earnings but also put players out of the game' (FIFPro 2001: 15). This formula would not even afford players the protection of a negotiated transfer fee. FIFPro also rejected the notion of a 'multiplier' within the transfer system which would have the result of inflating fees depending on criteria not related to the 'actual cost' of training. ${ }^{58}$ One of these multiplier criteria is the quality of the clubs youth section. Given the financial commitment of top clubs to youth academies, the revised transfer system proposed by FIFA/UEFA would result in resources flowing to these clubs and not from them. This defeats the redistribution argument for the maintenance of the transfer system as the dominant position of the top clubs is reinforced.

In short, the FIFPro report condemned proposals contained within the Negotiation Document on the revised transfer system and arrangements governing player contracts. In place of the revised transfer system, the FIFPro report recommended the establishment of re-distributional solidarity funds, a solution mooted by the Advocate General in Bosman. FIFPro suggested that the solidarity 'pool' would be composed of items such as a proportion of gate receipts, television revenues and merchandising. The legitimate objectives expressed by FIFA/UEFA of ensuring a balance between clubs and the encouragement of youth training would be better achieved through these funds than the restrictive transfer system. The FIFPro report expressed disappointment that both the national leagues and UEFA have failed to fully maximise the potential of such revenue sharing, instead relying on the questionable transfer system to do it for them. On the issue of player contracts, the FIFPro report proposed the use of collective bargaining. FIFPro General secretary, Theo Van Seggelen, threatened to 'go to court in every country' if the FIFA/UEFA proposals were accepted, a threat UEFA described as 'totally unacceptable'. ${ }^{59}$

\section{The FIFA-UEFA split}

The December 1999 Helsinki report on sport presented the Commission's position on the relationship between sport and the EU. In it, the Commission stressed that it would take the 'specific characteristics' of sport into account in the application of EU law if these characteristics could be adequately defined by the sports world themselves. The report placed a heavy emphasis on a partnership between the EU and a unified sports world. The dispute between FIFA/UEFA on the one hand and FIFPro on the other did little to communicate to the Commission the existence of a sports world with 
common concerns. In January 2001 the united front presented by FIFA and UEFA in the Negotiation Document also began to crumble.

The Commission's initial response to the Negotiation Document was cautious. In particular, in ongoing discussions with FIFA/UEFA, the Commission expressed concerns relating to the provisions on: the prohibition of the international transfer of minors, the maintenance of transfer fees for players under the age of 23 and the continued inability of players to end contracts prematurely.

FIFA's response to these concerns was to unilaterally issue a second set of proposals to the Commission in January 2001. FIFA explained: 'with a view to making progress in the negotiations with the European Commission on the reform of the international transfer system, FIFA has elaborated a document, which contains new proposals' ${ }^{60}$ The new FIFA document entitled 'Proposals to Amend FIFA's International Transfer Regulations' contained provisions which would have permitted players to serve three months notice on a club prior to the termination of contract.

UEFA issued a response to the new FIFA document in a media release on the 17 January $2001 .{ }^{61}$ In essence, UEFA felt that the new FIFA proposals on transfers undermined their efforts to resolve the dispute with the Commission. Furthermore, UEFA criticised FIFA for the way the new proposals were unilaterally submitted to the Commission. The mid-January news headlines were dominated by reports of a possible formal split between FIFA and UEFA unless the dispute between the two parties could be resolved. For UEFA this split could only be avoided if FIFA declared their new transfer proposals void. Given that FIFA, UEFA and FIFPro now all held competing visions for the future, a solution with the Commission seemed remote. The Helsinki partnership approach had failed to be utilised by the key football authorities. Clearly concerned at UEFA's implied threat, FIFA formally withdrew their transfer proposals on 19 January 2001. The October 2000 Negotiation Document reverted to the default document with which FIFA/UEFA would conduct further negotiations with the Commission.

\section{The Nice Summit}

In December 2000, the Heads of State and Government met in Nice to finalise the work of the intergovernmental conference. In essence the leaders of the $15 \mathrm{EU}$ countries met to sign a new Treaty designed to strengthen the internal structure of the EU prior to the enlargement of the Union to include applicant Central and Eastern European countries and Malta and Cyprus. In the run up to that meeting intense lobbying took place by the sports world for a protective protocol on sport to be attached to the new Treaty. Despite support for a protocol on sport from some of Europe's major footballplaying nations, no additional mention was made of sport in the Treaty beyond the Declaration annexed to the Amsterdam Treaty. As with the Amsterdam debate, the Commission opposed a legally binding mention of 
sport in the Treaty for fear of setting a precedent of allowing certain professions exemptions from the Treaty.

Despite this further setback for the game's governing bodies, the member states did release an unusually long Declaration on Sport in the form of a Presidency Conclusion. The provisions relating to the transfer dispute read, 'the European Council is keenly supportive of dialogue on the transfer system between the sports movement, in particular the football authorities, organisations representing professional sportsmen and -women, the Community and the member states, with due regard for the specific requirements of sport, subject to compliance with Community law'.

\section{The final transfer settlement}

Despite the split that emerged between FIFA, UEFA and FIFPro, the Nice Declaration offered football's governing bodies an ideal opportunity to secure a favourable settlement with the Commission. In March 2001 an agreement was reached between the Commission and FIFA/UEFA on the restructuring of the international transfer system for professional footballers. The agreement represented a compromise between the interests of the two parties and was widely interpreted as a favourable settlement for football's governing bodies. In July 2001 FIFA's Executive Committee adopted a new set of transfer rules in line with the principles agreed with the Commission in March. The new rules came into effect in September 2001 and were based on the following principles:

1 The protection of minors: the international transfer of players under the age of 18 is permitted subject to agreed conditions; the football authorities will establish and enforce a code of conduct to guarantee that training and sporting and academic education be provided.

2 Training compensation for young players: in the case of players aged under 23, a system of training compensation should be in place to encourage and reward the training effort of clubs, in particular small clubs.

3 Maintenance of contractual stability: contracts to be protected for a period of three years up to 28; two years thereafter. Sporting sanctions can be applied to players unilaterally terminating their contract within this protected time. Financial compensation can be paid if a contract is breached unilaterally whether by the player or the club.

4 Solidarity mechanisms: the creation of solidarity mechanisms (based on a proportion of compensation fees) is designed to redistribute a significant proportion of income to clubs involved in the training and education of a player, including amateur clubs.

5 Transfer windows: one transfer period per season, and a further limited mid-season window, with a limit of one transfer per player per season. 
6 Dispute resolution: a dispute resolution and arbitration body is established which does not prejudice the ability of players to seek other forms of legal redress. ${ }^{62}$

FIFPro's threat to 'go to court in every country' began in Brussels in May 2001. FIFPro sought to question the authority of the Commission to sanction a revised transfer system which FIFPro regarded as deviating from EU law. However prior to the hearing FIFPro applied for an adjournment. At the FIFA Congress at Buenos Aires in July 2001, FIFA announced how it intended to implement the new transfer system. FIFPro sought an adjournment in order to allow time to consider the details of FIFA's new system and include any new provisions in the proceedings. In particular, FIFPro expressed concerns relating to the implementation of the transfer provisions concerning sporting sanctions, the stability period and compensation payments for young players. Wishing the court case to be based on the 5 March agreement with the Commission, FIFA objected to the application for adjournment. In July the court granted the adjournment. In August, before the hearing was re-convened, FIFA and FIFPro reached an agreement on FIFPro's participation in the implementation of the new transfer regime. As part of the agreement, FIFPro agreed to halt their litigation in exchange for FIFPro representatives being able to sit on FIFA's Dispute Resolution Chamber along with representatives of the clubs. FIFPro will also nominate representatives for the new Arbitration Tribunal for Football, to which decisions of the Dispute Resolution Chamber can be appealed. Furthermore FIFA and FIFPro have clarified technical issues relating to the new transfer system and have agreed a system of review and consultation concerning the new system. The new transfer regulations accordingly came into force in September 2001.

The Commission now considers its scrutiny of the transfer system complete. The agreement between the Commission and FIFA consisted of an exchange of letters between the two parties in March 2001. In the Commission letter to FIFA, Commissioner Monti stated, 'your undertaking contains sufficient elements for me to be able to confirm that I no longer have the intention to propose that the Commission adopts a negative decision in the procedure that is open against FIFA as regards the international transfer rules'. ${ }^{63}$ In June 2002 the Commission released a press release in which it announced the formal closure of its investigations into FIFA's regulations on international football transfers. ${ }^{64}$ Following the entry into force of the new transfer procedure three complaints were withdrawn. Two remaining complaints relating to the transfer system were then rejected by the Commission thus allowing for the closure of the investigation. The two complainants were challenging the prohibition on players unilaterally terminating a contract. As complainants may have recourse to arbitration, national courts and the ECJ (in the later case to challenge the Commission's decision to reject the 
complaints), the Commission now considers its involvement over. FIFPro described this claim as 'premature'. ${ }^{65}$ Due to the informal nature of the settlement, the Commission does still have the right to re-open its investigation should it be dissatisfied with the implementation of the new transfer rules. Furthermore, it is clear that transfer rules are not considered by the Commission to be of purely sporting interest only. Future changes to the rules will continue to require Commission approval. The approach adopted by the Commission does not therefore settle the issue definitively. A challenge to the transfer rules before a national court and potentially the ECJ must therefore remain a future possibility.

In case C-264/98 Tiborbalog v. Royal Charleroi Sporting Club, the ECJ was expected to hear a case concerning objections to the international transfer system which mirror those of the Commission. Following the remodelling of FIFA/UEFA's international transfer system in March 2001, Tibor Balog (a non-EU player) and ASBL Royal Charleroi Sporting Club (RCSC) reached a settlement meaning that a preliminary reference to the ECJ was no longer required on the question of the movement of out-ofcontract non-EU players. Interestingly, before the case was withdrawn the Advocate General (Stix-Hackl) published a negative opinion in which she argued that such restrictions were incompatible with Article $81 .^{66}$

\section{The regulation of players' agents}

Of increasing importance to the supply and demand of players is the role of their agents. Following a number of complaints and two petitions from the European Parliament, in October 1999 the Commission launched an investigation into FIFA's rules governing players' agents. ${ }^{67}$ FIFA requires players and clubs to use licensed agents who themselves must provide a nonreturnable bank guarantee of 200,000 Swiss Francs. The Commission considers these rules as potentially anti-competitive as they may have the effect of denying individuals access to the profession. It is questionable whether the competitive-enhancing features of these rules outweigh their anticompetitive features. As such a less-restrictive approach to regulating player's agents may be proposed by FIFA in the future.

\section{Comment: a competition policy framework for sport}

The ruling in Bosman had profound consequences for sport. Not only did sport have to adjust to the terms of the ruling, it found itself operating in a new regulatory environment in which competition policy was central. Given the newly acquired commercial status of sport in Europe, the Commission found itself compelled to examine more closely the relationship between sport and competition law. In general, the Commission has consistently held that agreements between undertakings in the sports sector do fall within the scope of competition law. Nevertheless, as the above review of case law 
illustrates, the Commission is seeking to adopt a more soft-touch approach to dealing with the internal rules of sport. A number of factors explain this.

First, in a short space of time cases before the Commission mounted rapidly. The Commission has had to deal with up to 60 sports-related cases at any one time. This expansion of the Commission's sports-related caseload has placed a strain on the Commission's already over-stretched resources. In other sectors, this strain has resulted in a slow turnover of cases and the increased use of administrative procedures rather than formal decisions to decide cases. In two major cases concerning the operation of Formula One motor racing and the international transfer system for footballers, the Commission has followed an informal negotiated settlement approach rather than taking formal decisions.

Second, the increased involvement by the member states (and other actors in the EU) has compelled the Commission to review their procedures for applying competition policy to sport. The member states responded to postBosman criticism of the EU's approach to sport through the Amsterdam Declaration. Although the Declaration disappointed those who wished to see a legal competence for sport established within the Treaty, the Declaration has proved extremely significant. In particular, it launched the so-called new approach to sport - an approach which in terms of the application of EU law to the sports sector stressed the need to balance commercial calculations with a consideration for sports social, cultural and educational qualities. The Commission's 1999 'framework' paper (see below) was in effect an institutional response to the Declaration.

Finally, as the Commission has gained more experience in sports-related issues, so they are more able to formulate clearer guidelines on the application of competition law to the sports sector. Although the causistic approach by the Commission has appeared haphazard at times, an understanding of the sports sector can only develop with time and through consultations with interested parties.

Faced with the above developments, the Commission has sought ways to establish a new regulatory environment for sport, integrating sporting selfregulation within a EU competition policy framework. However, this separate territories approach has been constructed through a mixture of hard (formal) and soft (informal) law. As is explored below, this raises some important questions about the future viability of the current separate territories approach. The Commission's approach does nevertheless reject the notion of a general block exemption for sport. The Commission is still committed to the development and consolidation of the internal market and is keen to avoid setting a precedent for allowing certain professions exemptions from the Treaty. After all, sport cannot be considered to be the only sector with 'special' characteristics.

The then Competition Policy Commissioner Van Miert signalled his intention to establish such a competition framework for sport in November 
1997 at a meeting of the European Sport Forum held in Luxembourg. At this meeting Van Miert stated that 'positive action' must be taken in respect of sport. 'By positive action I mean providing the sporting world with guidelines on what kind of restrictions would be acceptable, given the special features of the sector concerned' (Van Miert 1997). In March 1998, the Competition Policy Director General Alexander Schaub made clear that these guidelines would not include a general exemption for sport from EU competition law. He argued that such an exemption is 'unnecessary, undesirable and unjustified' (Schaub 1998). Furthermore, Schaub made clear that the Commission still felt a strong sense of commitment to the realisation and protection of the fundamental freedoms. In this connection he remarked, 'it would not be fair to consumers and it would not reflect the economic importance of sport if we were merely to sit back and refrain from applying the competition rules. Where we receive legitimate complaints, we must take the necessary action' (Schaub 1998).

In February 1999, the Commission released a paper on the application of competition rules to sport. ${ }^{68}$ The paper was the first formal exploration of the separate territories concept. The paper outlined the following principles to be considered when applying EU competition rules to sport:

1 safeguarding the general interest in relation to the protection of private interests;

2 restricting Commission action solely to cases which are of Community interest;

3 applying the so-called de minimis rule, according to which agreements of minor importance do not significantly affect trade between member states;

4 applying the four authorisation criteria laid down in Article 81(3) of the EC Treaty, but also refusing an exemption to any agreements which infringe other provisions of the EC Treaty and in particular freedom of movement for sportsmen;

5 defining reference markets pursuant to the applicable general rules adapted to the features specific to each sport.

To provide some guidelines for assessing potential breaches of EU competition policy, the Commission has developed four categories concerning:

1 Rules to which, in principle, Article 81(1) of the EC Treaty does not apply, given that such rules are inherent to sport and/or necessary for its organisation.

2 Rules which are, in principle, prohibited if they have a significant effect on trade between member states.

3 Rules which are restrictive of competition but which in principle qualify for an exemption, in particular rules which do not affect a sportsman's freedom of movement inside the EU and whose aim is to maintain the balance between clubs in a proportioned way by preserving both a certain 
equality of opportunities and the uncertainty of results and by encouraging recruitment and training of young players.

4 Rules which are abusive of a dominant position under Article 82 of the EC Treaty. It is not the power to regulate a given sporting activity as such, which might constitute an abuse but rather the way in which a given sporting organisation exercises such power. A sporting organisation would infringe Article 82 of the EC Treaty if it used its regulatory power to exclude from the market, without an objective reason, any competing organiser or indeed any market player who, even meeting justified quality or safety standards, failed not to obtain from said sporting organisation a certificate of quality or of product safety.

The paper makes clear that as guidelines the principles contained in the paper do not prejudice the Commission's existing sports-related investigations. The paper represents something of a shift in thinking by the Commission and has had practical effects in connection with the application of competition law to sport (see above and below). Nevertheless, the limits of the competition law separate territories approach are apparent. Essentially, the Commission's line of reasoning on sport rests on the assumption that the commercial and regulatory functions of sport can be separated. Where sport is practiced as an economic activity, the Commission has indicated that restrictive practices will be challenged unless they can be justified on sporting grounds. In other words, if sports organisations can demonstrate that the pro-competitive features of their rules outweigh the anti-competitive features, the Commission should in principle have no objection.

The Commission will need to distinguish between purely sporting situations which would be considered to be outside the remit of EU competition law and wholly commercial situations, which are not. As the Commission's paper acknowledges, sport in Europe comprises two levels of activity,

on the one hand the sporting activity strictly speaking, which fulfils a social, integrating and cultural role that must be preserved and to which in theory the competition rules of the EC Treaty do not apply. On the other hand a series of economic activities generated by the sporting activity, to which the competition rules of the EC Treaty apply, albeit taking into account the specific requirements of this sector. ${ }^{69}$

The difficulty clearly lies in situations in which it is difficult to separate these two levels of activity. Furthermore, the difficulty in deciding which rules are inherent to the operation of sport and which are commercially based is apparent. As such any framework for applying competition policy to sport must be very broad in order to accommodate the huge diversity in the sports world. A case-by-case approach to sport is therefore likely to persist, calling into question the usefulness of the framework. Nevertheless, as case law develops so a clearer picture is emerging of the types of agreements that are being considered anti-competitive. In this connection the 
Commission is following a dual strategy. On the one hand it has consistently confirmed that sport is subject to competition law. On the other, it has then considered more closely ways in which the specificity of sport can be taken into consideration in the application of law. As such the Commission has not only been able to fulfil its constitutional role as guardian of the legal framework, it has also responded positively to political pressure for increased sensitivity. A review of the case law confirms this approach.

The exploitation market The Commission's approach to broadcasting has mainly centred on establishing competition within the broadcasting sector. The Commission has recognised that sports rights often form an essential part of any new broadcasting service being offered to consumers. Such rules are therefore essentially commercial in nature. Accordingly, in all of the broadcasting markets discussed above (collective selling, exclusivity, collective purchasing and transmission), the Commission has established that broadcasting rules fall within the scope of Article 81. The Commission's line of reasoning must therefore be seen in the context of their commitment to establish a single market in broadcasting services in which a range of operators, including those embracing new technology, play a full part. This is consistent with the Commission's line in other sectors. However, in each of these broadcasting markets, the Commission has demonstrated a willingness to make more use of exemptions than it has in other sectors. The Commission has therefore explicitly acknowledged the specificity of sport. In the case of Formula One for instance, the Commission acknowledged that the collective sale of broadcasting rights was appropriate for the sport. On ticketing arrangements, even though the Commission adopted a negative decision in the France 1998 case, the size of the fine (a mere 1,000 euros) indicated that the Commission had to once again balance commercial considerations with the specific nature of sport. Finally, in the cases to come before it concerning merchandising agreements, the Commission has consistently sought to limit the anti-competitive impact of exclusive distribution and sponsorship agreements. In this connection, the Commission has taken the view that such rules could not be justified on sporting grounds.

The contest market On first appearance, the issue of how sports bodies organise themselves would appear to fall outside the scope of EU competition law. This has not happened. The Commission has scrutinised a growing number of cases concerning the organisation of sport in Europe. Unlike with broadcasting rights where competition law was employed to free up the broadcasting market thus allowing for the entrance of new participants, competition law is applied to organisational issues as a way of maintaining a competitive balance between clubs. In both instances, the Commission argues that consumers benefit from such interventions. Hence the Commission has been sympathetic to rules which seek to maintain the single 
structure model of sport and rules restricting multiple club ownership and club relocation. Furthermore, in the Formula One case the Commission made a concerted effort to separate the FIA's regulatory and commercial functions.

The supply market In terms of player mobility, the Commission's line has essentially concerned the rights of players as workers and the rights of clubs as commercial undertakings. In terms of post-Bosman transfer rules, the Commission initially adopted a hard line. It made it clear that it was not prepared to accept alternatives to the transfer system that compromised EU law. However, the impact of the Amsterdam and Nice Declaration's on sport have altered this view. The March 2001 settlement on transfers reflects a more sympathetic approach to sport. The Commission has accepted the argument that restrictions on player mobility and restrictions on the ability of clubs to employ players without obstruction can be justified in terms of maintaining a competitive balance between participants. Again, therefore, the Commission has acknowledged the specificity of sport within the context of EU competition law.

In applying competition law to sport, the Commission has had to operate within the context of three institutional pressures. First, the Commission is committed (both ideologically and constitutionally) to the promotion and protection of free and fair competition in the Single Market. It is an institution deeply committed to the principles of negative integration. Second, the Commission faces administrative difficulties. The Competition Policy Directorate suffers from a lack of resources and consequently struggles to ensure the widespread application of competition law to all sectors of the economy. It is for this reason that the Commission is committed to reforming the procedures for applying competition law. Third, the Commission must square its commitment to free market principles with the political pressure being applied to it to recognise the specific characteristics of sport when applying competition law to the sports sector.

As a consequence of these pressures, the Commission's approach to sport has been shaped by the use of soft law - another institutional norm within the Commission. Soft law settlement of cases takes the form of the issuing of comfort letters, the publication of notices or even the publication of press releases. The Commission has used these informal channels to resolve cases involving Formula One motor racing, the operation of the international transfer system for footballers, UEFA's central selling of broadcasting rights (which may in time harden with a formal decision) and the issue of club relocation. The Commission has also made use of policy papers to communicate their thoughts on the application of competition rules to sport. The use of soft law allows the Commission to respond to political pressure for a softer touch application of competition law to sport whilst not undermining their 
commitment to the free market. Soft law also allows for the speedier and less costly turnover of cases. Furthermore sports bodies themselves favour the informal negotiated settlement approach. With the relationship between sport and competition law being a relatively new development, the use of soft law can also be defended on the grounds of flexibility and sensitivity to sport whilst the Commission build up experience of the sector.

Nevertheless, the use of soft law poses some important questions for sports relationship with the EU. In areas where the Commission has resorted to formal decision making such as in the case of UEFA's broadcasting regulations, ticketing arrangements and merchandising agreements, sport can rely on hard law principles to guide them. However, by using soft law, the Commission has in effect constructed legally fragile separate territories for some crucial arrangements in sport. As the Commission's role is central to the success of the separate territories approach, the continued use of soft law is potentially problematic. As the expanded territory of sporting autonomy is not fully underpinned by hard case law, sport cannot readily rely on the long-term soundness of the separate territories. Furthermore, should the Commission's proposals to amend the competition law procedure be adopted, a new set of actors will play an important part in the development of separate territories.

Under the Commission's proposals, in addition to the Commission, national courts and regulatory authorities will also be able to apply the exemption criteria outlined in Article 81(3). The devolution of the powers to apply Article 81 will allow the Commission to concentrate on the most serious abuses of competition law. Sport is unlikely to be considered such an important sector. As such, the national courts and competition bodies will play a more prominent role in the regulation of sport. However, the Commission's proposals assume that these bodies will be able to play a more active part in applying competition law as they are familiar with the competition law procedures and case law. In the case of sport, the Commission's use of soft law has however resulted in a dearth of hard law measures which could guide the national authorities. With the involvement of more, essentially Single Market regulatory actors operating within the sports policy subsystem, the number of available venues for litigants to exploit will also increase. Single Market regulatory 'venue shopping' therefore has the potential to undermine the legally fragile principles of the separate territories approach. As Kinsella and Daly argue, to compound the lack of 'hard' case law guidance, the impending enlargement of the EU will further erode the uniform application of competition law principles to sport (Kinsella and Daly 2001: 13). As the exemption criteria (both formal and informal) forms an essential tool in implementing the separate territories approach, the future remains uncertain.

The soft law sporting principles contained with the separate territories approach are therefore legally fragile. First, they can become undermined 
either by a change of approach by the Commission or through the impact of the Commission proposal. In such circumstances, sports bodies are likely to abandon their preference for soft law. They could, with some justification, claim that their legitimate expectations have been eroded by changes in the application of competition law. The Commission is to some extent bound by its informal decision making. Second, the socio-cultural coalition could exploit further institutional venues and themselves go 'venue shopping' in order to secure a more legally robust regulatory environment. Further subsystem activity in the form of coalition venue shopping will therefore undoubtedly change the current separate territories landscape.

The future definition of the separate territories therefore remains uncertain. Pressures such as the expected downturn in television revenues for sport may also impact upon the separate territories. Concerned at the financial health of many of Europe's football clubs, UEFA intends to introduce a club licensing system in the 2004/2005 season. Under the terms of the system, all clubs taking part in UEFA competitions must adhere to 'good governance' criteria. Given that high player salaries are at the root of football's financial problems, the system may act as a vehicle to administer the capping of salaries. The leading clubs in Europe have already agreed in principle to salary capping as a mechanism to control spiralling wage bills. As the details of the salary cap have yet to be published, the Commission has not formed an opinion on its compatibility with competition law. Salary caps are by definition restrictive. Depending on the form they take they restrict the amount clubs can spend on wages thus restricting the supply and demand for players. Capping is therefore likely to be caught within the scope of the EU's competition rules. However, if the financial recession in sport threatens to undermine the game itself, capping may be considered inherent to sport and essential to maintain a competitive balance between the clubs. The Commission's eventual treatment of salary capping will say much about the future definition of the separate territories. As far back as 1997, the Commission has however indicated its support for capping. As then Commissioner Van Miert remarked, 'another avenue which might be worth exploring is that of the salary cap whereby the total expenditure of each club on players' salaries would be limited so as to prevent all the good players joining the rich clubs, possibly with a levy on any clubs disregarding this limit' (Van Miert 1997).

\section{Notes}

1 COM (2000) 582 Final, 'Proposal for a Council Regulation on the Implementation of the Rules on Competition Laid Down in Articles 81 and 82 of the Treaty and Amending Regulations' (EEC) No. 1017/68, (EEC) No. 2988/74, (EEC) No. 4056/86 and (EEC) No. 3975/87. ('Regulation Implementing Articles 81 and 82 of the Treaty'), 27/09/00. 
2 Ibid., Section 2 a.

3 Cases 56 and 58/64, Consten and Grundig v. Commission [1966] ECR 299. Re: the use of exclusive distribution agreements, the granting of exclusive trademark usage and export bans in the electronics sector.

4 Case 56/65, Société Technoque Minière v. Maschinenbau Ulm [1966] ECR 235.

5 Regulation No. 870, 1995 and 1475, 1995.

6 COM (2000) 582 Final.

7 Commission Notice on the Definition of relevant market for the purposes of Community competition law, 1997, OJ C 372.

8 Stevenage Borough FC Ltd v. Football League Ltd [1997] 9 Admin LR 109, Times 1 August, 1996.

9 See Chapter 1.

10 Order of 2 September, 1994, B 6-747000-A105/92, WuW/EBkartA 2682.

11 Judgement of the Restrictive Practices Court (in England and Wales), 28 July 1999 in the matter of the Restrictive Trade Practices Act 1976 and in the matter of an agreement between the Football Association Premier League Limited and the Football Association Limited and their respective member clubs and in the matter of an agreement relating to the supply of services consisting in the broadcasting on television of such matches. The Act has since been replaced by the 1998 Competition Act.

12 Case No IV/37.214 - DFB (1999), OJ C 6.

13 Case No IV/37.398 - UEFA (1999), OJ C 99.

14 Of the total amount, 68.5 per cent is paid to the 24 clubs taking part in the UEFA Champions League (group matches).

15 DN: IP/01/1043. 20/07/01, 'Commission Opens Proceedings against UEFA's Selling of TV Rights to UEFA Champions League'.

16 DN: IP/02/806. 03/06/02, 'Commission Welcomes UEFA's New Policy for Selling the Media Rights to the Champions League'.

17 DN: IP/01/1523, 30/10/01, 'Commission Closes Its Investigation into Formula One and Other Four-Wheel Motor Sports'.

18 Council Directive 89/552/EEC as amended by Directive 97/36/EC.

19 Case 262/81, Coditel v. Ciné Vog Films SA [1982] ECR 3381 and the Decision of the Commission in Film Purchases by German Television Stations case, OJ L 248.

20 Case No. IV/33.245 - BBC, BSB and Football Association (1993), OJ C 94.

21 Case No. IV/36.033 - KNVB/Sport (1996), OJ C 228.

22 Commission Decision 91/130/EEC, OJ L 63.

23 Case No. IV/32.150, Commission Decision 93/403/EEC, OJ L 179.

24 Joined Cases T-528/93, T-542/93, T-543/93 and T-546/93, Métropole Télévision SA v. Commission [1996] ECR II-649.

25 Case No. IV/32.150, Commission Decision 2000/400/EC, OJ L 151, 24/06/00.

26 See Commission Press Releases DN: IP/00/372, 12/04/00, 'Commission Ready to Lift Immunity from Fines to Telefónica Media and Sogecable in Spanish Football Rights Case' and DN: IP/00/1352, 23/11/00, 'Commission Withdraws Threat of Fines against to Telefónica Media and Sogecable, but Pursues Examination of Their Joint Football Rights'.

27 Renamed Article 44 by UEFA in 1997. Article 47 of UEFA's Statute 2000 Edition. 
28 Case No. 37.576. UEFA's Broadcasting Regulations, Commission Decision 2001/478/EC OJ L 171, 19/04/01. See also Commission Press Release DN: IP/01/583, 20/04/01, 'Commission Clears UEFA's New Broadcasting Regulations'.

29 Cases IV/33.384 and IV/33.378 - Distribution of package tours during the 1990 World Cup, Decision 92/521/EEC (1992) OJ L 326.

30 Comité Français d'Organisation (1998), News Release, Paris 23/3/98.

31 Richard Corbett MEP Press Release, 21/5/98, 'Euro MP's Take World Cup Organisers to Court'.

32 Case No. IV/36.888 - 1998 Football World Cup, Commission Decision 2000/12/EC (2000), OJ L 5, 08/01/00.

33 Case C-206/01, Arsenal Football Club plc v. Matthew Reed.

34 Opinion of Advocate General Ruiz-Jarabo Colomer, Case C-206/01, Arsenal Football Club plc v. Matthew Reed, 13/06/02.

35 Case C-318/00, Bacardi-Martini et Cellier des Dauphins.

36 Commission Decision of 18/03/92, OJ L131.

37 Commission Decision of 21/12/94, OJ L378.

38 See Commission Notice OJ C 138, 09/05/96.

39 DN: IP/98/355, 15/04/98, 'The Commission Conditionally Approves Sponsorship between the Danish Tennis Federation and Its Tennis Ball Suppliers'.

40 Case No. IV/37.400 - Project Gandalf, OJ C 70, 13/03/99.

41 However, questions have been asked concerning the compatibility of the Media Partners Super-league proposal with EU competition law. See van den Brink, J.P. (2000a), EC Competition Law and the Regulation of Football: Part 1, European Competition Law Review, Issue 8.

42 See Case C-250/92, Gøttrup-Klim Grovvareforeninger and Others (1994) E.C.R. I-5641.

43 CAS 98/200 AEK Athens and Slavia Prague v. UEFA, 20/08/99, Lausanne, Switzerland.

44 Case COMP/37 806: ENIC/UEFA. See DN: IP/02/942, 27/06/02, 'Commission Closes Investigation into UEFA Rule on Multiple Ownership of Football Clubs'.

45 DN: IP/99/965, 09/12/99, 'Limits to Application of Treaty Competition Rules to Sport: Commission Gives Clear Signal'.

46 DN: IP/99/434, 30/6/99, 'Commission Opens Formal Proceedings into Formula One and Other International Motor Racing Series'.

47 Ibid.

48 See Notice published pursuant to Article 19(3) of Council Regulation No. 17 concerning cases COMP/35.163 - Notification of FIA Regulations, COMP/36.638 - Notification by FIA/FOA of Agreements relating to the FIA Formula One World Championship, COMP/36.776 - GTR/FIA and others (2001/C169/03), 13/06/01.

49 DN:IP/01/120, 26/01/01, 'Commission Welcomes Progress towards Resolving the Long-running FIA/Formula One Case'.

50 DN: IP/01/1523, 30/10/01.

51 Conversation with FIA member, November 2002.

52 PE DOC A3-0326/94, 27/04/94, 'Report on the European Community and Sport'. 
53 DN: IP/01/599, 'Commission Does not Object to Subsidies for French Professional Sports Clubs', 25/04/01.

54 German Government Press Release No.425/00. 09/10/00.

55 Joint FIFA/UEFA Negotiation Document (International Transfer of Players). Available at www.uefa.com, 10/01.

56 FIFPro is the Federation Internationale Des Associations De Footballeurs Professionnels.

57 Using Italy as an example, FIFPro's paper claims that player mobility rose from 15 per cent to 42 per cent in the period in question.

58 Such as a player's ability and potential and the number of players trained by a club.

59 BBC Online, 17/02/01.

60 FIFA Media Release 10/01/01, 'Principles for the Amendment of FIFA's Rules Regarding International Transfers', accessed at www.FIFA.com

61 UEFA Media Release, 17/01/01.

62 DN: IP/02/824, 'Commission Closes Investigations into FIFA Regulations on International Football Transfers', 05/06/02.

63 Letter from Mario Monti to Joseph S. Blatter, 05/03/01 D/000258.

64 DN: IP/02/824.

65 FIFPro press release 13/06/02, 'FIFPro Reacts to Statements of Commission and FIFA'.

66 Case C-246/98, Opinion of 29 March 2001.

67 DN: IP/99/782 21/10/99, 'Commission Launches Formal Proceedings on FIFA Rules Governing Players' Agents'.

68 DN: IP/99/133, 'Commission Debates Application of Its Competition Rules to Sport', 24/02/99.

69 Ibid. 